\title{
Where Does Privatization Work? Understanding the Heterogeneity in Estimated Firm Performance Effects *
}

\author{
J. David Brown \\ John S. Earle \\ Álmos Telegdy
}

May 2016

\begin{abstract}
Why do the reported effects of privatization on firm performance vary so much? This paper provides new estimates of these effects and tests potential explanations for heterogeneity using comprehensive, long-panel data for 70,000 firms in five East European economies. We estimate that privatization raises measures of profitability, productivity, and growth by about $5-12 \%$ on average, but with substantial variation across countries and time periods. Analyzing heterogeneity in privatization effectiveness, we find little systematic role for firm size, financial dependence, exchange listing, or technological complexity, but important variation by fraction privatized, ownership concentration, firm quality, and the macroeconomic and institutional environment.
\end{abstract}

Keywords: privatization methods, corporate governance, ownership structure, business environment, firm performance

JEL codes: G32, G34, L25, L33, P31

\footnotetext{
*Brown: IZA-Bonn, Earle: George Mason University (earle@gmu.edu), Telegdy: National Bank of Hungary, Central European University and Institute of Economics of the Research Centre for Economic and Regional Studies - HAS. We thank Anikó Bíró, Eszter Nagy, and Solomiya Shpak for outstanding research assistance, and Scott Gehlbach for collaboration on related work. Assembling and preparing the data for this project involved large teams of collaborators, and we are grateful for conscientious work by Gábor Antal, Anna Lovász, Guy Loury, and Mariann Rigó on the Hungarian data; Jing Cai on the Lithuanian data; Ioana Dan and Ruxandra Stefan on the Romanian data; and Natalia Akhmina, Tatiana Andreyeva, Serhiy Biletsky, Ivan Maryanchyk, Alexander Scherbakov, and Vladimir Vakhitov on the Ukrainian data. We are also grateful to EROC (Economic Research and Outreach Center at the Kyiv School of Economics) for support of Ukrainian data collection and preparation. Álmos Telegdy received support from the European Research Foundation's Starting Grant entitled "Measuring Knowledge Flows from Developed Countries to Central and Eastern Europe." The authors are responsible for all errors and conclusions, which are not shared by any of the organizations listed above. All errors are our own.
} 


\section{Introduction}

An enduring puzzle in research on the firm performance effects of privatization is why there is such a wide range in the reported estimates. Beginning with the classic paper on privatized firms by Megginson, Nash, and van Randenborgh (1994), most firm-level studies find positive effects on various measures of performance. However, the magnitudes vary widely across studies, with some large and some small estimates, some cases of a zero effect, and a few where the effects are estimated to be negative. Possible explanations for this variability include differences in the design of privatization programs, in the types of firms privatized, or in other aspects of the economic environment. Then again, the differences may result from variation in the types of data available for different countries, and in the outcome variables and estimation methods used in different studies. Therefore, it is uncertain whether the variability represents genuine differences or merely reflects the constraints and choices of different researchers estimating the privatization-performance relationship. ${ }^{1}$ Moreover, if the differences are genuine, it remains unclear what underlying characteristics of policies, firms, and the environment may account for these differences.

The purpose of this paper is to examine several important dimensions of heterogeneity in the firm performance effects of privatization. In order to obtain estimates that are reliable and comparable, we analyze most privatizations over a long time period with similar data for five countries: Hungary, Lithuania, Romania, Russia, and Ukraine. We also use a common set of firm performance measures, including measures of profitability, efficiency, and growth, to

\footnotetext{
${ }^{1}$ Other early multi-country studies include Boubakri and Cosset (1998), D'Souza and Megginson (1999), Frydman et al. (1999), and Claessens and Djankov (2002). Brown, Earle, and Telegdy (2006) represents a paper reporting a negative privatization effect for one country, Russia, although Brown, Earle, and Gehlbach (2013) find the Russian effect becomes positive in 2003-2005, as discussed below. The extensive literature estimating an average privatization effect consists primarily of studies of either single countries or small samples from many countries; excellent surveys can be found in Megginson and Netter (2001), Djankov and Murrell (2002), and Estrin et al. (2009).
} 
examine robustness in the patterns and sources of variation in estimated privatization effectiveness. The data size is much larger in both the cross-sectional and time-series dimensions than any previous study of privatization and it facilitates the use of econometric methods to identify causal effects, estimate how the estimates vary with observable factors, and carry out specification checks of alternative identification methods. Our empirical approach for estimating the average effects generally follows Brown et al.'s (2006) method for analyzing productivity, including a control group of state-owned firms within the same country-industryyears, fixed-effect and random growth models estimated with deviations from firm-specific means and trends, and specification checks for selection bias. However, our data set is more than twice as large and adds non-manufacturing sectors and a broader set of outcome measures. Our data also contain measures of firm, industry, and economy-wide characteristics that we use to investigate heterogeneity in privatization effectiveness, the main focus of this paper.

Our first step is to estimate the average effects of privatization with our large sample, examining alternative regression methods and dependent variables, including proxies for profitability (return on sales), efficiency (labor productivity), and growth (output or sales). The results are consistent with the findings from most previous studies in implying positive and highly statistically significant effects for firm performance. The magnitudes depend somewhat on the specification, and our specification checks reject OLS estimates as unreliable but provide some support for both a specification with only firm fixed effects (FE) and for one with firmspecific time trends also included (i.e., a random growth model, which we label FE\&FT). The results for the FE and FE\&FT specifications lie in the five to twelve percent range for each of the outcome variables. When estimating separately by country, we find substantial variation that largely confirms, although with a much larger database and more firm performance measures, 
the general pattern reported in Brown et al. (2006); we also find significant variation over time periods and across industries. The evidence further suggests that the cross-country variation is an artifact neither of sample coverage nor of reporting behavior.

Having established that at least some of the variation in privatization effectiveness appears to be real, we turn to the principal question of this paper: what factors are responsible for the heterogeneity? Although previous research on privatization offers much discussion on this question, it provides relatively little systematic analysis of the sources. The closest papers to ours are Frydman et al. (1999), D’Souza, Megginson, and Nash (2005), and Boubakri, Cosset, and Guedhami (2005), who analyze variation in privatization effects along some of the same dimensions. A disadvantage of those studies is that the samples consist of short time series on 218,129 , and 230 privatized firms respectively, and data limitations preclude the use of control groups, comparisons within industries and years, and adjustments for trends. Brown, Earle, and Gehlbach (2009) examine heterogeneity in privatization effects across Russian regions, but only for manufacturing firms and with a focus on interactions with state bureaucracy. Bartel and Harrison (2005) analyze privatization in Indonesia with a focus on hardening budget constraints. We build on this research in our analysis below.

Our analysis of the heterogeneous effects considers three sets of hypotheses, discussed here only briefly but explored more thoroughly in the relevant sections below. The first concerns variation in privatization policies and in the resulting new ownership structures. We first confirm previous findings with our much larger samples that the effectiveness of privatization is considerably higher when the new owners are foreign investors rather than domestic individuals or businesses. To focus the remaining discussion, we restrict attention subsequently to domestic privatizations. Concerning the domestic privatization effects, we find a strong relationship with 
the fraction of shares privatized, so that 100 percent privatizations produce larger performance effects than do majority privatizations short of 100 percent. In contrast to both types of "control privatization" types, partial privatizations that lead to a minority of shares in private hands (minority or "revenue privatizations") are estimated to produce little or no positive impact on any of the measures of firm performance. ${ }^{2}$ The data for two countries (Hungary and Romania) permit us to distinguish different methods of domestic privatization resulting in different levels of ownership concentration and insider involvement: direct sales to large blockholders, mass privatization with vouchers that leads to extremely dispersed outside shareholding, and management-employee buyouts (MEBOs) that result in predominance of insiders. Voucher privatization estimates sometimes imply little or no effect, while MEBO estimates show consistently positive effects. Both, however, tend to have smaller effects on efficiency than the domestic blockholders, which, again, are dominated by foreign investors. On the other hand, we find no consistent evidence that stock exchange listing (share issue privatization, SIP) conveys benefits greater than the associated ownership change. Thus, our analysis shows a strong relationship between some aspects of privatization policy design (and consequential ownership structure) and how effectively privatization raises firm performance.

The second set of hypotheses concerns firm characteristics that may influence the degree to which private versus state ownership matters. One issue concerns the "quality" of the state owned enterprise (SOE) undergoing privatization. Although somewhat mixed, the evidence suggests that poorer performing firms (measured by pre-privatization productivity) improve

\footnotetext{
${ }^{2}$ Previous research on minority privatization is somewhat inconclusive. $\mathrm{Li}$ and $\mathrm{Xu}$ (2004) find no effects in telecommunications, Gupta (2005) finds positive effects in India, Sun and Tong (2003) find no effects in China, while Jiang et al (2009) and Bai et al. (2009) do find effects in China. Berger et al. (2009) also find positive effects in banking, although their privatizations involve foreign ownership. A difference between these studies and ours is that they focus on share issue privatizations, where the effect of ownership change and the disciplinary effect of listing on the stock exchange appear simultaneously, while we are able to distinguish these two mechanisms.
} 
more post-privatization compared to better performing firms. A second issue concerns the firm's operational complexity, considered here through firm size and technology usage within the firm's industry. We find weak evidence that smaller firms tend to benefit more from privatization, but find no statistically significant relationship with technology use. Theoretically, an important channel for privatization benefits may be improved access to financial markets, we find little difference in the effectiveness of privatization between industries with high and low levels of financial dependence and between firms with high versus low capital intensity. To summarize, we find only weak relationships between privatization effectiveness and hypothetically related firm characteristics measured or captured by proxies in our data.

Finally, the analysis includes several macroeconomic and institutional factors. We find a strongly negative relationship between the estimated effects of privatization on firm performance and the extent of price inflation. This suggests that clear price signals are necessary for new private owners to restructure and improve results. We also study the relationship between privatization effectiveness and growth at both the aggregate (GDP) and industry levels. We find strong positive effects, particularly at the industry level, suggesting that private owners may have an advantage when responding to growth opportunities. Finally, using a summary measure of the large variation in institutional and business environments across countries and time, our estimates suggest that stronger market reforms in dimensions other than privatization tend to raise the impact of privatization on firm performance. The result that privatization and other reforms are complementary is consistent across outcome variables and estimation methods. Overall, we find that economic environment plays a very important role in conditioning the effectiveness of privatization. 
We organize the paper as follows. Section I describes the economic contexts and privatization policies in the countries we analyze. Section II summarizes our data and Section III the empirical strategy. Section IV provides results for the average effect of privatization in the pooled sample and specification checks on alternative estimators. It also reports results separately by country to motivate the subsequent examination of possible factors accounting for effect heterogeneity. We divide the heterogeneity analysis into three subsections within Section $\mathrm{V}$ : the first on privatization policies and ownership structure, the second on firm and industry characteristics, and the third on the macroeconomic and institutional environment. Section VI concludes the paper with a synthesis of the evidence.

\section{Policies and Context}

This paper analyzes comprehensive data on firm-level privatization transactions in five East European economies that began radical transitions from centrally planned to market economies in the early 1990s: Hungary, Lithuania, Romania, Russia, and Ukraine. These countries offer several advantages for study. Like other economies of the region, they engaged in massive privatization programs in the first decade of transition, providing a large number of privatized firms for study. At the same time, a large number of SOEs remained in state hands through the end of our sample period, constituting a natural control group, together with the notyet-privatized firms, for estimating the effects of privatization. Moreover, the available data on privatized and state-owned firms for these countries is large in both the cross-sectional and timeseries dimensions, including over 70,000 enterprises observed in an unbalanced panel for up to 20 years. The large number of firms allows us to engage in more "apples-to-apples" comparisons than would be possible with a smaller data set, in particular permitting us to 
estimate within industry-year cells. The long time series stretching back into the preprivatization period facilitates the use of panel econometrics including fixed-effect and random growth models. Data for other transition economies are unavailable to us, but our sample countries' data coverage and variable definitions are quite similar to each other, enabling a comparative analysis.

These countries also display a great deal of heterogeneity in both their specific policies and their broader economic contexts, heterogeneity that we exploit in our analysis. To start with, the overall pace of institutional transition differs considerably between the countries. As one measure of the "progress in transition," the European Bank for Reconstruction and Development (EBRD) started an indicator tracking not only privatization but also key elements of the market transition: governance and enterprise restructuring; liberalization of prices, foreign exchange, interest rates, and trade; and reform of banking and infrastructure. ${ }^{3}$

Figure 1 reports the overall scores by country and year. Each country begins the transition with a score close to zero. Hungary, which engaged in some partial reforms in the 1980s (and even earlier, dating back to the "Goulash Communism" of the early 1970s), exhibits the highest starting score, though this remains low at 0.18 . The situation changes radically in the early 1990s however, as some countries adopt "big bang" reforms while others take a more gradualist approach. By the end of our sample period, the scores for all five countries have greatly increased, though with substantial variation. Hungary is judged closest to a market economy, with a score over 0.8 . Lithuania and Romania occupy a second group with a score of about 0.65 , while Russia and Ukraine have scores close to 0.5. Russia's reversion to a lower score presents

\footnotetext{
${ }^{3}$ As published by the EBRD, these indicators for multiple dimensions of reform range from 1, denoting an unreformed, centrally planned economy, to 4.3, denoting a full market economy. For greater convenience, we rescaled these values to run from 0 to 1 . In addition, because the indicators are highly correlated within a given country and year, we have taken a simple average within country-year cells to summarize the development of market institutions in these countries.
} 
an interesting anomaly, possibly reflecting the EBRD analysts' re-evaluation of the Russian reforms' authenticity. In any case, leaving aside questions regarding the scores' inevitable subjectivity, our data capture this remarkable variation in the institutional environments surrounding privatized (and state-owned) enterprises. We will explore in more detail below whether a better business environment enhances the effectiveness of privatization in raising firm performance, so that the two factors are complements or, alternatively, whether they are substitutes such that privatization generates more improvement when the general environment contains few other factors to incentivize firm performance. ${ }^{4}$

The macroeconomic environments in our study also vary greatly across countries and years. Figure 2 shows the evolution of measured GDP for the five countries, including the "transformational recessions" in the 1990s and subsequent general recovery. While the exact magnitude of the GDP decline is controversial, because of changes in the quality and availability of goods and the accuracy of price statistics, the cross-country differences in the size of the recession and the pace of recovery are striking (Kornai 1994; Lipton and Sachs 1990). For our purposes, such variation provides an opportunity to test whether privatization is more effective in an expanding or contracting environment. We also investigate this issue using a finer measure of demand conditions, namely the growth in output in the firm's industry. One hypothesis is that private owners are more entrepreneurial during expansions, more energetically and creatively pursuing new growth opportunities, but have little relative advantage at cost-cutting during contractions.

The sample countries display large variation along other macroeconomic dimensions as well. Open unemployment rose rapidly during the early transition, peaking at double-digit levels

\footnotetext{
${ }^{4}$ A related issue is whether concentrated ownership is more effective when legal protections are weaker; see LaPorta, Lopez-de-Silanes, and Shleifer (1998).
} 
by the late 1990s. Each country experienced bouts of high inflation following price liberalization, and in Ukraine hyper-inflation even reached a 90.8\% monthly rate in December 1993 (State Statistics Service of Ukraine, 2014). We use this variation to investigate whether clear price signals - and stable economic conditions more generally - are especially valuable for private owners seeking to restructure firms and improve performance. If inflation clouds these signals, it could reduce privatization's effectiveness.

Our study countries also differ in how their privatization policies cover different property types such as land, housing, shops, and small service establishments (e.g., Barberis et al. 1996; Earle et al. 1994). These types of privatization likely had consequences for the business environment, but our focus here is the privatization of businesses as going concerns, the socalled "large privatization." Each country had multiple programs for privatizing businesses, with each program producing a different ownership structure. To the extent the data permit, we use this within-country heterogeneity to investigate the relative effectiveness of different privatization methods. The remainder of this section describes in more detail the methods and tempos of large privatization in the five countries we study.

Compared to the other countries in our sample, as well as most other transition economies, Hungary was unusual both in starting the privatization process early and in maintaining a consistent emphasis on case-by-case sales. At the very beginning, transactions tended to be "spontaneous," initiated by managers, sometimes in combination with foreign or other investors. Beginning in 1991, the sales process became more regularized, generally relying upon competitive tenders open to foreign participation, although managers frequently gained control, often in partnership with domestic or foreign investors. Unlike elsewhere, Hungary showed no significant preferences for the acquisition of shares by non-managerial employees, nor did it 
offer a mass distribution of shares through vouchers. Consequently, the Hungarian privatization resulted in few firms with either dispersed or worker ownership. About 250 firms were privatized in a special program via management-employee buyouts (MEBOs), but anecdotal reports suggest managerial dominance even in these cases. As a result, Hungarian privatization generally led to significant managerial ownership and concentrated blockholdings, many of them foreign (Frydman et al., 1993a). Although the process appeared slow and gradual at times, it proceeded more quickly than in most other East European countries.

In Romania, by contrast, early attempts to mimic voucher programs and sell individual firms produced few results. Privatization began in earnest only in late 1993 with the MEBO program, after a small pilot program conducted at the end of 1992. This was followed by the voucher privatization program of 1995-96 that resulted in a very high degree of ownership dispersion in a varying percentage of privatized shares. (Earle and Telegdy, 2002). These programs resulted in large-scale employee ownership and dispersed shareholding by the general population with little foreign participation. Beginning in 1997 foreign investors became more involved. Blocks of shares were sold to both foreigners and domestic entities, while MEBOs continued. The result was a mixture of several ownership types, more variation in ownership concentration, and a moderate privatization speed compared to Hungary.

In its early stages, the Lithuanian privatization also favored employee ownership. Although the legislation allowed for case-by-case sales, private owners of former SOEs were typically employees acquiring either 30 or $50 \%$ of the shares with vouchers at a low price. As a result, about $65 \%$ of the former SOEs had majority employee ownership (Mygind, 1997). By the time our data starts in 1995, the privatization law favored the sale of SOEs to outside domestic and foreign investors (Grigorian, 2000). 
Russia and Ukraine's earliest privatization experiences have some similarities to the "spontaneous" period in Hungary, as the central planning system dissolved in the late 1980s and decision-making power devolved to managers and work collectives (Frydman et al., 1993b). The provisions for leasing enterprise assets (with eventual buyout) represented the first organized transactions in 1990-1992. However, most Russian industrial enterprise privatization occurred from October 1992 to June 1994 when shares were transferred primarily to managers and other employees who received large price discounts (Boycko, Shleifer, and Vishny, 1995). Some shares, generally 29 percent, were reserved for open voucher auctions. These resulted in a variety of ownership structures including dispersed outside shareholders, voucher investment funds, and domestic blockholders. A few foreign investment cases also developed. Blockholding and foreign ownership became more significant through later share block sales and secondary trading. Ukraine used somewhat different mechanisms but generally followed Russia's pattern at a slower pace. In both countries, the initial result involved large-scale ownership by insiders and some blockholding by domestic entities. Concentration and foreign ownership subsequently increased.

Figure 3 shows the evolution of the private share in our sample, which consists of firms completely or majority state-owned at first observation, the set of enterprises at risk of privatization. Starting from zero in each country, the percentage of firms becoming 100 percent or majority privatized rises sharply during the transition. ${ }^{5}$ It rises first in Hungary, followed by Russia, Romania, Ukraine, and Lithuania. ${ }^{6}$ In this figure and for most of our analysis in this paper, we define a firm as private if more than 50 percent of its shares are privately held. ${ }^{7}$

\footnotetext{
${ }_{6}^{5}$ See Table A1 for precise definitions of the ownership variables.

${ }^{6}$ The proportions are generally smaller than those reported in other studies because of data differences and some country-specific peculiarities. The most important factor is that we include firms from all industries, while like most other studies such as Brown et al. $(2006,2010)$ used only manufacturing, which has a higher share of privatization
} 
In Table 1, which shows a more detailed breakdown of ownership structure for the sample firms, however, the top panel also includes minority or partial privatizations to domestic investors. ${ }^{8}$ These are less common than majority (but less than 100 percent) and complete (100 percent) privatizations, with the latter category the largest in all countries. ${ }^{9}$ The sample nevertheless contains many observations in each category, enabling us to estimate their separate effects on firm performance. The table also distinguishes privatizations to domestic and foreign owners, and the bottom panel contains a breakdown of domestic ownership by privatization method: MEBO or voucher privatized, defined according to whether the largest owner-type has acquired its shares in MEBO or voucher privatization programs, respectively. The percentage of firms majority privatized to foreigners is highest by far in Hungary, reaching nine percent by 2004, while the share falls between one and three percent in the other countries. Given our sample sizes this is still enough to estimate a foreign effect.

Our data distinguish different privatization methods only in Hungary and Romania. Hungary primarily used sales to outside investors, but about 250 firms were transferred to their employees. Policymakers in Romania experimented with all major forms of privatization, giving a large number of firms away to their employees and transferring shares in others to the public through vouchers. By the end of the study period, insider-privatized firms make up 27 percent of

(and usually of foreign-ownership) than nonmanufacturing. The privatization rate in the sample is also lower in Lithuania because the data start only in 1995 and in Ukraine because the non-industrial firms enter the sample only in 1997, as described in the data section below.

${ }^{7}$ Ownership is measured at year-end. The Hungarian and Russian data contain no ownership information before 1990 and 1993, respectively. For Hungary, we assume that firms are state-owned up to 1989. For Russia, virtually all the privatizations in our data are mass privatizations which started only in October 1992, so we also assume state ownership through 1992. The other countries contain ownership codes from the beginning of the time series.

${ }^{8}$ Megginson et al. (1994) and others distinguish "control privatizations" from "revenue privatizations" on the basis of whether a majority or minority of shares are privatized. Here, a private firm is defined as domestic if more shares are held by domestic than by foreign investors, and as foreign otherwise (nearly all foreign privatized firms by this definition are majority foreign-owned).

${ }^{9}$ While the other countries have continuous ownership variables for share percentages, the Russian variable is categorical: state, mixed state-private, 100 percent private, and foreign (including joint ventures). Other evidence suggests the mixed state-private would be nearly always majority private (e.g., Boycko et al., 1995), so we have placed them in this category for our analysis in this paper. 
all former Romanian SOEs. Voucher privatization resulted in joint majority ownership by domestic individuals, with a highly dispersed structure, in 19 percent of the firms. ${ }^{10}$

\section{Data}

Our analysis draws on annual panel data for most of the firms inherited from the socialist period in the five countries we study. ${ }^{11}$ The data sources and variables are quite similar across the five countries. The State Committees for Statistics in Lithuania (Statistikos Departamentas), Russia (Goskomstat), and Ukraine (Derzhkomstat) compile the annual enterprise registries that form the basic databases for our analysis in these countries. We supplement these databases with joint venture registries available in Russia and a database from the State Property Committee in Ukraine, both of which we have linked across years for our analysis. The Lithuanian data cover 1995-2006, the Russian 1985-2005, and the Ukrainian 1989 and 1992-2006. The whole Russian and the early Ukrainian data sets (through 1996) are based on industrial registries that supposedly include all industrial firms (manufacturing as well non-manufacturing) with more than 100 employees or more than 25 percent ownership by the state and/or legal entities themselves included in the registry. In practice, firms appear to remain on the registry even if the original conditions for inclusion are no longer satisfied. As a result, the data may be considered quite comprehensive with respect to the "old" industrial sector of firms inherited from the Soviet system. The whole Lithuanian dataset and the Ukrainian data starting in 1997 contain all firms regardless of size, ownership, and industrial affiliation.

\footnotetext{
${ }^{10}$ In Romania, we observe all privatization transactions but not subsequent sales among private parties. We classify a firm as insider or voucher privatized for all the years it is observed after privatization. In Hungary we can identify subsequent sales, but for comparability we treat these firms in the same way as in Romania.

${ }^{11}$ The data used by Brown et al. $(2006,2010)$ is a substantially smaller subset of the data used in this paper. Those studies included only the manufacturing sector, while here we add non-manufacturing firms in all countries, one additional country (Lithuania), two more outcomes (return on sales and output), and several extra years to the panel database.
} 
The Hungarian and Romanian data are generally more similar to each other than to those in the Soviet successor states. The basic data derive from the National Tax Authority in Hungary and the Ministry of Finance in Romania, each providing data for all legal entities engaged in double-entry bookkeeping. We supplement the Romanian data with the National Institute for Statistics' enterprise registry and two datasets from the State Ownership Fund describing its portfolio and the privatization transactions. The Hungarian data are available for 1986-2005 and the Romanian data for 1992-2006.

We exclude non-profit organizations in each country, as well as Russian firms subordinated to the State Committee for the defense industry after 1998. We retain firm-years in the sample only when they contain information on the two variables used in each of our regressions: ownership and industrial affiliation. Finally, we only include firms that are state-owned at first observation because de novo firms are not at risk of privatization, and our panel data methods rely on ownership change for identifying the effects of privatization. The base category thus consists exclusively of state-owned firms.

These data have required extensive preparation to fill in missing values, remove inconsistencies, and improve missing longitudinal linkages caused by firm identifier changes (reorganizations, legal form changes, etc.). Missing values have been replaced and inconsistencies evaluated using information from multiple sources, including previous year information available in Romanian balance sheets and Russian and Ukrainian registries. We have improved the longitudinal linkages using all available information to match firms existing in a given year with those entering in the following year. Such information includes industry, region, size, multiple financial sources, and some exact linking variables like firm names and addresses (in all countries except Hungary, where this information is not available). In Hungary, 
we have also employed a database with information on firm reorganizations, including reregistration. If a firm changed its identification number for some reason, and it appeared in the data as a new entry or an exit, the database indicates whether it had a predecessor or successor and if so, that firm's identification number.

Variables showing highly volatile fluctuations have been removed if they meet any of the following criteria. For employment, real sales, and real capital, we reset the variable value to missing if it increases by a factor greater than five, then declines by a factor greater than five; increases by a factor greater than ten after first entry to the data; or decreases by a factor of ten in the final year of observation. ${ }^{12}$ We set net income to missing if it increases (decreases) and then decreases (increases) by more than two standard deviations, either in two consecutive years or in the entry or exit year. We also set return on sales to missing if the absolute value of the variable is larger than five.

Table 2 contains the number of firms and firm-year observations for state-owned enterprises and domestic and foreign privatizations that we use in the output regressions. ${ }^{13}$ The total number of firms is 71,470 and the total number of firm-years is 645,848 . The substantial number of always state-owned firms $(32,272)$ provide a useful control group for estimating the privatization effects for both domestic-privatized $(37,522)$ and foreign-privatized $(1,676)$ firms, even if the foreign are less numerous than the domestic. The Lithuanian data contain the smallest number of observations, so industry-year cell sizes are much smaller than elsewhere, implying noisier estimates for this country. Although not shown in the table, the average time

\footnotetext{
${ }^{12}$ These cleaning rules reduce the regression samples by less than 0.3 percent and have negligible effects on the results.

${ }^{13}$ The number of observations by country is provided in Appendix Table C0. The precise definitions of domestic and foreign ownership in privatized firms are provided in the previous section. There are some cases when privatization is observed, but not the nationality of the private owners. There are others with two ownership changes (state-domestic/foreign and another between domestic and foreign). The number of ownership switches between domestic and foreign or vice versa is 343 in Hungary, 20 in Lithuania, 6 in Romania, 82 in Russia and 248 in Ukraine.
} 
series length for privatized firms varies across countries from 4.5 to 8.1 years pre-privatization and 6 to 9.6 years post-privatization. Missing values for particular variables do not reduce the sample much. Entry and exit make the panel unbalanced. ${ }^{14}$

Table 3 shows summary statistics for the dependent variables and their components (see Table A1 for variable definitions). The financial variables are deflated by two-digit, industrylevel GDP deflators and transferred into 2005 USD. Average net income is positive in each country, and the average per-firm employment numbers range from 107 in Lithuania to 679 in Russia, reflecting the large size of former SOEs and the skewed industrial distribution in the Russian data. We use return on sales (ROS) as our financial efficiency measure, defined here as the ratio of net income to the value of sales. Operating efficiency is measured by labor productivity (LP), the value of real sales per employee. The growth measure is sales (Output).

\section{Empirical Strategy}

Our basic questions are whether and under what circumstances private versus state ownership matters for firm performance. Early research on the "whether" question examined private and state firms that did not change ownership and therefore relied entirely on crosssectional variation (e.g., Caves and Christensen 1980). The static comparison in this approach has the obvious drawback that unobserved factors may drive both ownership and performance so that selection bias competes strongly with causality as an interpretation of any observed ownership-performance relationship. Studying privatization (or nationalization) has the advantage of introducing additional identifying information from firm switchers and permitting controls for unobserved factors. Of course, a randomized, controlled trial might overcome the

\footnotetext{
${ }^{14}$ Private entrants are excluded from the sample, but state-owned entrants (resulting from split-ups or reregistering) are included since they may be privatized subsequently.
} 
selection bias more convincingly, but we know of no privatization program involving random selection.

Another important estimation issue is defining a control group that provides a baseline for the "treated," privatized firms. Early research using data exclusively on privatized firms lacked "non-treated" comparison firms, and thus had to rely on the changes in performance indicators post-privatization relative to pre-privatization; essentially the pre-privatization period becomes the control group (e.g., Megginson, Nash, and van Randenborgh 1994). However, this approach cannot distinguish the measured change from aggregate or firm-specific trends from the same period. In this study, we form a control group from never-privatized SOEs together with the preprivatization years of subsequently privatized firms. We identify the privatization effect by comparing switchers between state and private ownership with non-switchers.

Another issue in defining the control group is similarity in basic characteristics, particularly industry. Much privatization research analyzes data containing few observations in each industry and thus relies on cross-industry variation, comparing privatized firms in one industry with state-owned firms in a different industry (e.g., Earle and Estrin 1998). Including industry fixed effects does not address differences in growth or shocks across industries that could correlate with privatization likelihoods. ${ }^{15}$ Moreover, available price deflators and exchange rates may not capture relative price levels and changes in the sample countries. To remove such effects, our regressions control for a full set of country-industry-year interactions. The estimates thus represent the difference between privatized firms and controls within the same country, industry, and year. ${ }^{16}$

\footnotetext{
${ }^{15}$ Defining outcome variables as deviations from their industry-level counterparts normalizes the effects around industry averages, but does not take into account heterogeneity and selection within industries.

${ }^{16}$ We control for 2-digit industries, of which there are 55 in each country except in Russia, where the data cover only the industrial sector (28 2-digit industries). The number of years is 20 in Hungary, 12 in Lithuania, 15 in
} 
Even within the narrowly-defined cells given by these three-way interactions, selection bias remains possible. Politicians, bureaucrats, managers, employees, and investors may influence whether a firm is privatized. Politicians concerned with unemployment may prefer state ownership for firms with the worst prospects, to protect workers from layoffs and wage cuts. In such cases, employees may oppose privatization. Potential owners would likely prefer firms with better prospects. Our strategy includes firm fixed effects (FE) in the regression to control for any time-invariant, unobservable factors that affect selection and firm performance. In some specifications, we also add firm-specific trends (a specification we label FE\&FT) to control for differences in performance growth. We also carry out specification checks to examine evidence on any residual selection bias after these procedures have been applied.

The basic specification for our panel data model, estimated on all firms initially observed as state-owned, takes the following form:

$$
y_{i j k t}=\mathbf{D}_{\mathbf{j k t}} \gamma_{\mathbf{j k t}}+\mathbf{w}_{\mathbf{t}} \boldsymbol{\alpha}_{\mathbf{i}}+\boldsymbol{\theta}_{\mathbf{i t}} \boldsymbol{\delta}+u_{i j k t},
$$

where $i$ indexes firms, $j$ indexes $J$ industries, $k$ represents $K$ countries, and $t$ represents $T$ years. In alternative specifications, the dependent variable $y_{i j k t}$ is return on sales (ROS), labor productivity (LP), and sales (OUTPUT). $\quad \mathbf{D}_{\mathbf{j k t}}$ is a $1 \times \mathrm{x} J K T$ vector of industry-country-year interaction dummies; $\gamma_{\mathbf{j k t}}$ is the associated $J K T$ × 1 vector of coefficients; and $u_{i j k t}$ is an idiosyncratic error. ${ }^{17}$ The dimensions of the other terms vary across specifications: $\mathbf{w}_{\mathbf{t}}$ is a vector of aggregate time variables, $\boldsymbol{\alpha}_{\mathbf{i}}$ is the vector of associated individual-specific slopes, $\boldsymbol{\theta}_{\mathbf{i t}}$ is the vector of ownership measures, and $\boldsymbol{\delta}$ are the ownership effects of interest in this paper. In the OLS regressions $\mathbf{w}_{\mathbf{t}} \equiv 0$. In the FE regressions $\mathbf{w}_{\mathbf{t}} \equiv 1$ such that $\boldsymbol{\alpha}_{\mathbf{i}} \equiv \alpha_{i}$ is the unobserved effect.

\footnotetext{
Romania, 16 in Ukraine, and 21 in Russia. To control for heterogeneity, the analysis thus permits up to 4,053 country-industry-year cells. Some are lightly populated, however, in which case they receive little weight in the regression estimates.

${ }^{17}$ Our estimates permit general within-firm correlation of residuals using Arellano's (1987) clustering method. The standard errors of all our test statistics are robust to both serial correlation and heteroskedasticity.
} 
The FE\&FT model specifies $\mathbf{w}_{\mathbf{t}} \equiv(1, t)$, such that $\boldsymbol{\alpha}_{\mathbf{i}} \equiv\left(\alpha_{1 i}, \alpha_{2 i}\right)$ where $\alpha_{1 i}$ is a fixed unobserved effect and $\alpha_{2 i}$ is a random trend. ${ }^{18}$

We investigate several alternative specifications for the ownership variables $\boldsymbol{\theta}_{\text {it. }}$ The simplest involves a dummy for private ownership. That is, $\theta_{i t}=1$ during the post-privatization period for privatized firms and $\theta_{i t}=0$ both for the pre-privatization period and for continuously state-owned firms. In this case, the parameter of interest, $\boldsymbol{\delta} \equiv \delta_{p}$ represents the mean withincountry-industry-year difference in the dependent variable between privatized firms and majority state-owned firms. ${ }^{19}$ Separate coefficients by country come from permitting $\theta_{i t}$ to vary by country so that $\boldsymbol{\theta}_{\mathbf{i t}}=\theta_{i t} \mathbf{D}_{\mathbf{k}}$ where $\mathbf{D}_{\mathbf{k}}$ is a vector of country dummies, and $\boldsymbol{\delta}$ is then a vector of country-specific privatization effects. We similarly distinguish foreign from domestic privatizations with $\boldsymbol{\theta}_{\mathbf{i t}} \equiv\left(\right.$ Domestic $_{i t-1}$, Foreign $\left._{i t-1}\right)$, and $\boldsymbol{\delta} \equiv\left(\delta_{d}, \delta_{f}\right)$, and effects in different time periods with $\boldsymbol{\theta}_{\mathbf{i t}} \equiv\left(\right.$ Private $_{i s}$, Private $\left._{i s}{ }^{\prime}\right)$, where $s$ and $s$ ' refer to different periods of years, and $\boldsymbol{\delta} \equiv$ $\left(\delta_{s}, \delta_{s}\right)$

We also estimate dynamic specifications, where dummy variables for the years before and after privatization are interacted with indicators for whether the firm is ever domestically privatized or foreign privatized. We designate $\tau$ as the index of event time (the number of years since privatization) such that $\tau<0$ in the pre-privatization years, $\tau=0$ in the year in which ownership change occurs, and $\tau>0$ in the post-privatization years. Then $\boldsymbol{\theta}_{\mathbf{i t}} \equiv\left(\right.$ Private $\left._{\mathbf{i t} \tau}\right), \boldsymbol{\delta} \equiv$ $\left(\boldsymbol{\delta}_{\tau \mathbf{p}}\right)$, and $\tau=-3-,-2,-1,0,1,2,3,4,5+$, where -3 - is three and more years before privatization, and $5+$ is five and more years after privatization. The privatization year $(\tau=0)$ provides the

\footnotetext{
${ }^{18}$ In practice, the FE\&FT model is estimated in two steps, the first calculating residuals from OLS regressions of each variable on a linear trend for each firm separately and the second estimating the model on the detrended data.

${ }^{19}$ We infer privatization when a firm changes from state to private status between the end of one year and the next. This implies that the date the new owners acquire formal authority (e.g., the first post-privatization shareholders' meeting) varies across firms, with some early in the final pre-privatization year. Some assumption on the first "post" year is necessary in this analysis, but as our estimates of the dynamics of the effect suggest, the results are not at all sensitive to this assumption.
} 
regressions' omitted category. We use dynamic ownership specifications to implement specification tests and evaluate how well the OLS, FE, and FE\&FT models deal with selection bias.

Our method generalizes the Heckman and Hotz (1989) "pre-program" test for equality of the conditional expectations of the outcome for the treated and control groups in a single pretreatment period. The identification assumption is that once the test is satisfied, the treatment represents the only cause of differences between the two groups after that period. We carry out $t$ tests of $\tau=-1$ and -2 to address Heckman, LaLonde, and Smith's (1999) concern that if a shock close to the treatment date affects one group but not the other, then the results may be sensitive to the choice of pre-treatment period. In addition to the pre-program test, we conduct $F$ tests on the joint probability that all FEs $=0$, and on the joint probability that all FTs $=0$ in regressions with a single post-dummy for privatization.

As reported below, our initial analysis of average privatization impacts finds statistically significant results for all measures of firm performance. Permitting the effect to vary by country, time period, and domestic versus foreign ownership reveals considerable variation, however. The uniformly larger effects for foreign compared to domestic privatizations lead us to focus on the latter in the subsequent analysis of possible explanatory factors for the variation in effectiveness. Our method involves further extensions of the ownership variables $\boldsymbol{\theta}_{\text {it }}$, and thus heterogeneity in $\boldsymbol{\delta}$, as we consider in turn the variation with respect to privatization method, percentage privatized, firm and industry characteristics, and the macroeconomic and business environment. 


\section{Estimating the Average Privatization Effect and Country-Time Variation}

We start by estimating the average privatization effect $\delta_{p}$ for the three firm performance measures: return on sales (ROS), labor productivity (LP), and Output. Table 4 shows OLS, FE, and FE\&FT specifications of Equation (1) for these dependent variables, estimated on the pooled sample of initially state-owned enterprises. The results consistently imply that privatization raises firm performance. The estimated effects are largest in the OLS specification, where the coefficient is 0.06 for ROS and 0.24 for LP and Output. This specification compares outcomes for state and private firms within industry-year cells, but otherwise makes no adjustment for heterogeneity and selection bias. To control for time-invariant firm characteristics that may affect selection, we include firm FEs. These provide qualitatively similar results to the OLS, but the coefficient magnitudes are smaller: 0.05 for ROS, 0.12 for LP, and 0.10 for Output. The FE\&FT specification, which also controls for selection varying with a linear time trend, produces qualitatively similar estimates but slightly smaller in magnitude: 0.03 for ROS, 0.08 for LP, and 0.06 for Output. While the differences across specifications suggest that important selection mechanisms accompany privatization, the data consistently imply that privatization raises financial and operating performance and growth. Even with the rather demanding FE\&FT specification, the privatization results are positive, significantly different from zero, and economically meaningful. ${ }^{20}$

To investigate selection bias more closely among these specifications, and to shed light on the dynamic process of privatization, we estimate specifications disaggregating the privatization

\footnotetext{
${ }^{20}$ Coefficient estimates using industry-year interactions with more aggregated sectors (the nine sectors described below) rather than the two-digit level we employ are qualitatively similar for the OLS and FE\&FT, but they tend to be smaller overall, and for two of the three dependent variables they are statistically insignificant for the FE. We strongly prefer our specification because it compares firms under more similar conditions, and thus it is closer to an apples-to-apples comparison.
} 
effect into years of event time, as described in the previous section. The coefficients on the preprivatization years, $\tau=-1,-2$, and $-3-$, may reflect the degree of selection bias in the level and trend performance of privatized firms. The results are shown in Figure 4, and the estimated coefficients and standard errors are presented in Appendix Table B1. The estimated preprivatization coefficients are frequently large in the OLS results, although they usually suggest negative rather than positive trends for firms about to be privatized relative to remaining stateowned enterprises. All the pre-privatization coefficient estimates are much smaller in the FE and FE\&FT specifications, and the FE\&FT are smaller than the FE, implying that the FE\&FT specification may be the most successful in removing systematic pre-privatization differences between state and to-be-privatized firms. Visual inspection also suggests that the FE specifications imply little change in the time trend in the relative performance of privatized compared to state-owned firms from before to after privatization. Therefore, we cannot rule out the possibility that the FE results reflect systematic differences in trend growth. In contrast, the FE\&FT results exhibit a sharp break in the trend as the coefficients decline slightly before privatization and increase strongly afterwards.

Table 5 establishes these results more formally. The top panel of pre-program tests shows that the $t$-tests on the pre-privatization coefficients in the OLS specifications are always statistically significant, while two are insignificant in the FE, and six are insignificant in the FE\&FT specifications. Even when individual coefficients are statistically significant, the implied trends in the FE\&FT specifications, visible in Figure 4, are negative rather than positive. Based on these tests, therefore, we prefer the FE\&FT specification. We also present the FE 
results as a robustness check, but the OLS specification is clearly inferior, and it is not considered further in this paper. ${ }^{21}$

The bottom panel of Table 5 shows tests for a break in trend growth of the dependent variable from before to after privatization, measured as an F-test on the equality of the difference between the coefficient estimates for $\tau=3$ and $\tau=1$ and the difference between the coefficients $\tau$ $=-1$ and $\tau=-3$. Of the three FE specifications, only that for $R O S$ shows a statistically significant break in trend growth, but all the FE\&FT specifications show pronounced trend breaks from before to after privatization. Thus, the specification which appears to perform best in terms of eliminating selection bias associated with differential levels or trends in performance is also the specification that produces the clearest evidence of a privatization effect.

As the purpose of this research is to understand heterogeneity in these average privatization effects, a natural starting point is to examine variation across countries. Figure 5 contains estimates where the private ownership coefficient is permitted to vary by country (Appendix Table C1 contains the estimates of coefficients and standard errors in this Figure; Appendix C also contains estimates separately by country). The results are generally consistent across performance measures, with the largest estimated effects for all measures in Romania, followed by Hungary. In Lithuania, the effects are small and insignificant for ROS and OUTPUT, but the LP estimate is as large as Hungary's. The effects are small but positive in Ukraine, though significantly different from zero only for LP. All the Russian estimates are negative (but significant only for LP). By these measures, privatization was most successful in Romania and Hungary where effects on all performance measures are positive and statistically significant. In Lithuania and Ukraine this is true only for operating efficiency (LP), whereas Russian operating efficiency is estimated to fall after privatization. The estimated cross-country differences are not

\footnotetext{
${ }^{21}$ F-tests on the joint significance of the fixed effects and trends are all statistically significant.
} 
only statistically significant but also economically meaningful. For operating efficiency, for example, the estimates range from -5.3 to 25.4 percent in the FE specification and -4.6 to 13.5 percent in the FE\&FT specification.

A second dimension of heterogeneity useful to consider from the outset is variation over time. In our data, a natural division is the early versus late transition periods, where the early period involves large institutional changes and economy-wide restructuring, while the later period reflects some consolidation and, for three of the sample countries, accession to the European Union. Other breakpoints could be used, but to illustrate this heterogeneity, Figure 6 (Table B2) reports results from regressions in which the privatization coefficient is permitted to vary between the "early transition period," defined as all years in the data through 2000, and the "late transition period," defined as 2001 and afterwards. The results imply substantial and statistically significant impacts of privatization for both periods according to all specifications and outcome measures. They also show a consistently higher estimated impact in the later period, suggesting that temporal variation in privatization effectiveness may be an important dimension. $^{22}$

A final basic dimension of heterogeneity concerns variation in privatization impacts by sector of industry. Figure 7 (Table B3) contains FE and FE\&FT estimates by sectors, defined as groups of NACE letters (grouped for sample size reasons and for clarity of presentation). It is striking that none of the 54 coefficient estimates (three dependent variables, two estimation methods, and nine sectors) are negative and statistically significantly different from zero. Some of the coefficients are imprecisely estimated, but many are positive and statistically significant.

\footnotetext{
${ }^{22}$ The higher estimated impact of privatization in the later period holds for most variables in all the countries. Particularly interesting is the reversal for more recent years of Brown et al.'s (2006) finding, using data only though 2002, that privatization in Russia had a small negative effect on productivity. Similar to the finding recently reported in Brown et al. (2013), we estimate a small negative coefficient through 2000, but a positive, statistically significant effect thereafter.
} 
They vary across industrial sectors fairly systematically with dependent variables and estimation methods, but certain sectors stand out for the general higher coefficients: construction (F); wholesale and retail trade and hotels and restaurant $(\mathrm{G \& H})$; and transport and communication (I). The utilities (electricity, gas, and water, sector E) sector exhibits the smallest impact of privatization. Clearly, the cross-industry heterogeneity is an important additional dimension to take into account. Our methods always control for disaggregated two-digit industry shocks, and some of our variables examine industry characteristics that may account for the sectoral differences.

This paper's main purpose is to investigate such potential sources of heterogeneity as privatization policy design, firm characteristics, and economic environment. Before we turn to that analysis, one possibility worth considering is that the cross-country differences could simply be statistical artifacts. First, they may reflect variation in the sample coverage rather than genuine differences across the countries. The entire Russian data set and the first six years of the Ukrainian data set contain only industrial (goods-producing, mining, manufacturing, and utilities) firms. In contrast, the other datasets include firms from all sectors. To test the effect of sample coverage, we reproduce the results for comparable samples containing only industrial firms. As shown in the Appendix (Table C1), restricting the sample to industrial firms generates the same results and country rankings based on the estimated effect on LP and Output. The picture is murkier for ROS, though, where the FE implies positive effects (except in Lithuania), while the FE\&FT implies a positive effect for Romania only. ${ }^{23}$

The degree to which firms evade taxes presents a second potential source of bias. If the extent of underreporting is uncorrelated with ownership, the degree of underreporting will not

\footnotetext{
${ }^{23}$ The table also presents the results from non-manufacturing industries including agriculture, construction, and services. The ranking of countries by the size of the privatization effect is again the same.
} 
affect our results. If, however, private enterprises have stronger incentives to avoid or evade taxes (engaging in more misreporting than SOEs), this could impart a downward bias to our estimates (as Zhuravskaya (2007) argues is the case in Russia). Additionally, differences across countries in relative private-state tax avoidance may affect the privatization effectiveness rankings. To investigate this issue, we use the EBRD-World Bank Business Environment and Enterprise Performance Survey (BEEPS), which included a question on tax avoidance in the 1999 and 2002 waves. $^{24}$ Enterprise managers were asked "What percentage of the sales of a typical firm in your area of activity would you estimate is reported to the tax authorities, bearing in mind difficulties with complying with taxes and other regulations?" Using this variable as a proxy for tax avoidance, we run a regression explaining this variable with three types of ownership (state-owned, privatized, and new private) interacted with country dummies. We control for country effects, three employment size categories, six industry dummies (mining, construction, manufacturing, transportation, services, and other industries), and interactions between employment size and industry. The coefficients of the interactions between country dummies and the private ownership dummy provide a measure of tax avoidance by privatized firms relative to SOEs in the same country.

The results imply that privatized firms hide a larger share of their revenues than SOEs, although the estimated coefficients are quite small in magnitude. The coefficients are largest in Hungary and Lithuania, where privatized firms hide 7 percent more of their revenues than do SOEs. Values are smaller for Russia (3.7 percent), Romania (1.3 percent), and Ukraine (essentially zero), implying no difference between privatized companies and SOEs. Taking these results into account would raise estimated effects of privatization by these percentages, but the effects are not large, and they do not change the countries' privatization performance rankings,

\footnotetext{
${ }^{24}$ The data are available at http://ebrd-beeps.com/data/.
} 
although enough is added to the Russian LP coefficient to make it approximately zero. Of course, understating inputs and costs, for which we lack an indicator like the BEEPS survey for output, could work in the opposite direction. In any case, this exercise suggests that misreporting has limited consequences for estimates of the average privatization effect or for the variation across countries.

\section{Sources of Heterogeneity in Privatization Effectiveness}

Having established the validity of measured variation in privatization's effectiveness in raising firm performance, we now turn to potential explanations for this heterogeneity. In turn, we consider privatization policy design, pre-privatization firm characteristics, and the macroeconomic and business environment.

\subsection{Heterogeneity in the Privatization Effect by Policy Design and Ownership Structure}

A major choice in privatization program design concerns the degree of foreign participation. Foreign owners are generally controversial because while they may introduce new technologies, management practices, and access to finance and markets, they create concerns about "giving away the family silver." How much to encourage or limit their participation is one of the basic aspects of a privatization policy, and therefore we begin our analysis of heterogeneity with this issue. Moreover, because privatization results differ greatly for foreign investment compared with domestic privatization, excluding foreign privatization will be useful for subsequent analyses focusing on heterogeneity in domestic privatization outcomes.

Figure 8 (Table B4) shows the results when we permit the estimated coefficient in Equation (1) to vary according to new ownership type: foreign or domestic. The estimates imply that both 
types raise firm performance in both the FE and FE\&FT specifications. With the exception of the foreign privatization effect on ROS in the FE\&FT specification, all estimated domestic and foreign coefficients are statistically significantly different from zero. With the same exception, the foreign coefficients are larger than the domestic coefficients, and the difference is statistically significant and substantial in magnitude. For instance, the difference is more than three times for LP in the FE specification ( 0.383 for foreign versus 0.115 for domestic) and more than twice in the FE\&FT specification ( 0.166 versus 0.076$)$. This pattern is also robust across countries, with a broad pattern of higher foreign investor impacts (see Appendix Table C3). Because these differences are so large, the rest of the paper focuses upon heterogeneity in the domestic privatization effects (while controlling for foreign ownership).

Privatization methods resulting in predominantly domestic ownership include case-by-case sales of large blocks of shares to outside investors. Some observers (e.g., Kornai, 2000) believe this method to be best (following sales to foreigners) for encouraging performance-enhancing restructuring. Problems with the sales method include insufficient demand and political difficulties, compounded by problems of valuation. ${ }^{25}$ Other common methods include Management-Employee Buyouts (MEBOs) and mass-voucher privatization schemes. Both employ partial giveaways to circumvent problems with a lack of effective demand. Employee ownership may improve work incentives and company loyalty (Bonin, Jones, and Putterman, 1993), and widely dispersed ownership among employees may facilitate takeovers by outsiders (Aghion and Blanchard, 1996). But employees may lack the necessary skills, capital, and access to markets and technologies necessary to turn their firms around. In addition, corporate governance by employees may function particularly poorly when the firm requires difficult

\footnotetext{
${ }^{25}$ These difficulties may explain why only three transition countries - East Germany, Hungary, and Estonia adopted sales as the principal privatization method.
} 
restructuring choices involving disparate distributional impacts within the firm. ${ }^{26}$ Mass-voucher programs may avoid high levels of inside ownership, but in Russia and Ukraine they were combined with strong preferences for employees using their vouchers to acquire shares in their employer. The prevalence of highly dispersed ownership structures - a problem sometimes addressed through the creation of intermediaries - either by the state through the program (e.g., in Poland and Romania) or by private parties competing for individuals' vouchers (e.g., in the Czech Republic, Russia, and Slovakia) - presents another serious problem with these programs. Although little empirical evidence exists on the effects of these programs, a number of authors have been highly critical of them. ${ }^{27}$

As discussed in Section I above, programs with vouchers and insider preferences existed to varying extents in most of the countries in our sample. The cross-country variation in privatization effectiveness may reflect these policy differences, but they cannot be fully distinguished from other factors. In Hungary and Romania, however, the data permit us to distinguish MEBO from other types of privatization. We are also able to distinguish voucher privatization in Romania. The latter program led to an extremely dispersed ownership structure (Earle and Telegdy, 1998), providing a model case for our analysis.

Figure 9 (Table B5) shows the results generated by permitting the domestic privatization coefficient to vary by privatization method: voucher, MEBO, and domestic sale. The theoretical arguments suggesting block-holders produce better improvements in firm performance, followed by MEBO and voucher privatization methods receive partial support in the data. Sales to outside

\footnotetext{
${ }^{26}$ See Hansmann (1990) for this argument in explaining the patterns of worker ownership in Western economies. Frydman and Rapaczynski (1994) and Lipton and Sachs (1990) argue against privatization to employees, while Ellerman (1993), Stiglitz (1999), and Weitzman (1993) argue in favor. The relative roles of managers and workers and the institutional form of employee ownership, including voting and share trading practices, are discussed by Earle and Estrin (1996).

${ }^{27}$ See, e.g., Stiglitz (1999); Black, Kraakman and Tarrassova (2000); Kornai (2000); Spicer, McDermott, and Kogut (2000); and Roland (2001). Proponents of such programs include Lipton and Sachs (1990), Blanchard et al. (1991), Frydman and Rapaczynski (1994), and Boycko et al. (1995).
} 
domestic investors (block-holders) produce the strongest impact upon LP in both the FE and FE\&FT specifications, but the results for other dependent variables are more ambiguous. Only the voucher method fails to produce consistently positive and statistically significant coefficients, where the estimate is positive but statistically insignificantly different from zero for LP and small and negative (statistically insignificant) for Output in the FE\&FT specifications. MEBOs on the other hand, trail behind sales to outside domestic investors only slightly and their estimated impacts are sometimes greater (on ROS and Output in the FE specification). ${ }^{28}$

Another aspect of privatization policy design that we can address systematically with our data concerns the degree of control given to the new private owners. The clearest case is a total (100 percent) privatization, and while common in sales to foreign investors, it is less frequent with domestic privatizations (as shown in Table 1). When the state keeps a minority stake, it preserves a potential channel of influence over company behavior, which may be especially relevant in politically sensitive questions like downsizing. On the other hand, the firm may benefit from more favorable treatment (subsidies, procurements, or preferential tax treatment) in return for high employment levels or other services (Boycko et al., 1996). When the state retains a majority in "revenue privatizations", the situation is more ambiguous, as the state retains formal control. If the state is a passive owner, a private owner can de facto control the firm with a smaller equity stake, leading to greater divergence of cash flow and control rights and creating incentives for asset stripping and the pursuit of private benefits. ${ }^{29}$ While previous empirical analysis of revenue or partial privatizations have reported mixed results, as noted above, our

\footnotetext{
${ }^{28}$ As noted above, these estimates contain both the effect of the initial post-privatization ownership structure and also subsequent sales as the MEBO and Voucher variables are constant throughout the post-privatization period.

${ }^{29}$ Burkart et al. (1998) show theoretically that the smaller the controlling shareholder's share of cash flow rights, the more corporate resources it will allocate for private benefits.
} 
sample is orders of magnitude larger, including not only stock market transactions, and distinguishes total from majority privatizations.

In Figure 10 (Table B6), we report results from a specification disaggregating domestic privatizations into three types: total (100 percent), majority (but less than 100 percent), and minority (less than 50 percent). The results are strikingly systematic across outcome variables and specifications. Total privatization always generates the strongest effect, typically twice the size of the corresponding coefficients on majority privatization. Although much smaller than the estimated effects of total privatization, the coefficients for majority privatization are always positive and statistically significant. In contrast, the estimated coefficients for minority privatization are negative for every performance measure and econometric specification, and two-thirds of them are statistically significantly different from zero.

In light of these results, it is interesting to revisit cross-country differences in the average privatization effect. If we allow country-specific coefficients on domestic privatization to vary with total, majority, or minority privatized, as above, we find the same basic findings for each country separately (as shown in Appendix Table C5). In all cases where the coefficients are precisely estimated enough to provide a ranking, total and majority privatization produce much stronger impacts than minority privatization, and total has a larger impact than majority privatization. Minority privatization is always estimated to produce the smallest impact, but it is sometimes positive, sometimes negative, and usually statistically insignificantly different from zero. For Russia, where the data do not distinguish minority privatizations, it is notable that the coefficients for total privatization are always higher. When negative, they are usually not 
statistically significantly different from zero. The Russian picture therefore looks less dire when we focus on total privatizations. ${ }^{30}$

A final type of privatization policy that we can analyze is share-issue privatizations (SIP), involving stock-exchange listing and typically minority private ownership. As argued by Gupta (2005), for instance, stock exchange presence may enhance monitoring and provide feedback (through share prices) that discipline and incentivize management, although previous evidence is mixed on this question, as noted above. The share of SIPs in all privatizations is smaller in our sample countries than in non-transition economies where stock exchanges and other supporting institutions (investment banks, underwriters, valuation consultancies) are better developed, but there are 107 firms for which we can identify listing date in four of the countries; information for Lithuania is unavailable, so we exclude this country from the analysis. A possible difference compared with other countries is that SIP is frequently combined with another method, such as voucher, MEBO, or block sale. Rather than investigate all the possible combinations, we focus on whether the preceding results are affected in any systematic direction by listing. The results, which are available on request, are inconsistent across methods and dependent variables: coefficients on interactions of ownership variables (foreign, domestic, minority) are sometimes positive, sometimes negative, and most often statistically insignificant. These data therefore show no clear support for the hypothesis that listing raises firm performance beyond the effects of ownership change, but both the under-developed state of financial markets in these countries

\footnotetext{
${ }^{30}$ A related issue is whether the state keeps control of even majority privatized companies through pyramid structures and golden shares, which Bortolotti and Faccio (2009) show are common in a sample of 141 privatized and partially privatized companies in 22 countries (not including any of those in our data). Unfortunately, our databases contain no information on golden shares or ultimate control (derived from chains of ownership), which is a caveat to our analysis. On the other hand, the state as well as individual bureaucrats and politicians have means to affect the behavior of even fully private firms through both sticks and carrots. In this context, our analysis simply attempts to assess whether the transfer of shares matters at all for firm performance.
} 
and the small sample of listed firms available for analysis should be borne in mind when interpreting this result.

In summary, the results provide strong evidence that some aspects of privatization policy matter. The largest difference in firm performance is associated with foreign versus domestic ownership. We also find a distinction between buyout methods (sale to outside domestic investor or MEBO) versus a voucher give-away, although evidence of positive effects exists even for the latter (especially in the FE specifications). Little difference exists between sales to outside domestic blockholders or to employees, however, nor between SIPs and other forms of privatization. When interpreting all of these results, note that our data generally do not track secondary sales of privatized shareholdings. For example, a voucher-privatized firm whose shares are later bought up by a foreign investor would still be counted as domestic and voucherprivatized in our data. Finally, we find a strong relationship between percentage privatized and the impact on firm performance. By far the strongest privatization impact comes about with a total privatization, and majority privatization clearly dominates minority privatizations that preserve state control.

\subsection{Heterogeneity in the Privatization Effect by Firm Characteristics}

Next, we explore how differences in the quality, complexity, and financial dependence of firms matter for the privatization-performance relationship. To avoid endogeneity problems, we measure each characteristic in the year prior to privatization. Our methodology parallels the previous subsection, extending Equation (1) with interaction terms that permit heterogeneity in the average privatization effect. ${ }^{31}$

\footnotetext{
${ }^{31}$ Table A2 contains definitions and sources for the variables representing dimensions of heterogeneity in this section and the one following.
} 
The "quality" question has been much debated with respect to the sequence in which firms should be, or empirically tend to be, privatized. For instance, Gupta et al. (2008), Szentpeteri and Telegdy (2010), and Dinc and Gupta (2011) find that more profitable or productive firms tend to be privatized earlier for the Czech Republic, Romania, and India respectively. However, little or no attention has been paid to whether poorly or strongly performing firms tend to benefit more from privatization. Well-functioning SOEs may be better privatization candidates than those that are struggling, or, alternatively, it is possible that privatization may generate bigger effects for firms farther from the frontier. To analyze this issue, we use a simple measure of quality: the deviation of the firm's labor productivity in the year before privatization from the average productivity in the same country-industry-year. The results, presented in Figure 11 (Table B7), show that the estimated coefficient on an interaction term between pre-privatization productivity and domestic privatization tends to be negative for both ROS and LP. Hence, relatively unproductive firms gain more from privatization. The FE\&FT results imply that a 50 percent distance between two firms in pre-privatization productivity leads to a difference of 1.4 percentage point difference in the ROS effect of privatization and 3.1 percentage point difference in the LP effect. Privatization's estimated output effect, however, does not seem to differ by preprivatization productivity.

Even if private ownership always produces performance at least as good as state ownership, the relative advantage may vary across firm types in ways revealed in estimates of privatization effectiveness. For example, private owners may have a comparative advantage in managing larger, more complex firms through greater nimbleness in responding to market opportunities and superior incentive design skill and management practice. On the other hand, large firms may face more government interference in restructuring. We measure firm size as 
the deviation of the firm's employment in the year of privatization from the average in the same country-industry-year. As shown in Figure 11 (Table B7), the estimated coefficients on the interaction term between domestic ownership and firm size are all negative in the FE\&FT specification. This suggests that larger firms benefit less from privatization. A doubling of employment size, for example, leads to a two percent reduction in LP after privatization. Firm size varies from a few employees to tens of thousands in our sample, so the heterogeneity of the effect is large.

Advanced technology usage introduces a second aspect of firm-level complexity. Firms with heavy technology usage generally operate in rapidly changing market segments where private owners may have distinct advantages and a greater incentive to innovate (Hart, Shleifer, and Vishny, 1997). ${ }^{32}$ As a proxy for this variable, we use an OECD classification grouping industries by low, medium, and high information technology usage (OECD, 2011). We interact dummy variables for high usage and medium usage with domestic private ownership in an extension of Equation (1). Results for the high usage dummy are shown in Figure 12 (Table B8). The estimated high usage coefficients vary considerably across dependent variable specifications. While all the FE\&FT coefficients are positive, implying a larger privatization effect for technology-using firms, the coefficients are generally small and statistically insignificant. For instance, the FE\&FT estimate of the difference between high and low technology usage is 0.018 with a standard error of 0.051 . Thus, we find little evidence of this factor's importance, although our data may be too poor to measure it reliably.

A final firm characteristic is financial dependency. If increased access to finance provides an important channel through which private ownership improves firm performance, then

\footnotetext{
${ }^{32}$ Private firms may also invest more effectively. Brown et al. (2012) find that productivity returns to information technology investment vary across ownership types in Ukraine.
} 
privatization effectiveness may vary depending on the degree to which firms depend on external finance. ${ }^{33}$ We approach this issue two ways. The first uses a proxy for industry-level financial dependency using Ondko's (2012) calculations based on Rajan and Zingales' (1998) approach, measuring external financial dependence as the share of capital expenditures not financed by cash-flow from operations. We interact a dummy for "high financial dependence," defined as industries with a median financial dependence above the sample median, with the domestic privatization dummy to generate the coefficients shown in Figure 12 (with details in Table B8). The results are inconclusive. While the FE result for LP seems to support the story with a positive, statistically significant coefficient of 0.072 , no other coefficient is statistically significant, and the FE\&FT estimates are tiny. As a result, we find little support for privatization effectiveness varying with financial dependency. The minimal difference found in the estimates of privatization effects for the industrial versus non-industrial sector reinforces this conclusion (Table B3).

These results rely on industry-level variation, and unfortunately our databases do not contain variables enabling us to calculated financial dependence at the firm-level. As a substitute, we can compute capital intensity, defined as the firm's capital-labor ratio relative to the 2-digit industry average in year before privatization, and as before we interact this variable with domestic privatization to estimate how the impact of privatization varies. The results, which are available on request, again suggest little variation along this dimension: the interaction terms are tiny and statistically insignificant for labor productivity, and indeed the only significant result with FE\&FT is for ROS, for which the interaction coefficient is actually

\footnotetext{
${ }^{33}$ Knyazeva, Knyazeva, and Stiglitz (2009) find an association between public sector financing constraints and postprivatization investment growth among telecommunications firms.
} 
negative. Again, the results do not suggest that financial dependency plays a substantial role in accounting for the variation in estimated privatization effectiveness. ${ }^{34}$

\subsection{Heterogeneity and the Economic Environment}

The final set of potential dimensions of heterogeneity in privatization effectiveness concerns the economic and institutional environments. Private ownership may have a stronger advantage over state ownership in a situation of growth where owners and managers may have more opportunity for entrepreneurial decision-making (e.g., Frydman et al. 1999, Brown et al. 2010). The advantage may also be larger when price signals are unclouded by inflation and when complementary institutions like well-functioning legal systems exist for contract enforcement and investor protection (e.g., Djankov and Murrell 2001). Alternatively, active private ownership may substitute for rather than complement these aspects of the environment. As such, the benefits from privatization may be greater in weaker macro-economic and institutional situations. ${ }^{35}$ The argument is analogous to Demsetz and Lehn's (1985) thesis on ownership concentration, namely that privatization is more effective when other disciplinary devices are weak. To investigate these hypotheses we take advantage of the dramatic policy changes found in multiple countries during our data's long time series. Our environmental measures include GDP growth, industrial output growth, consumer price inflation (CPI growth), and business environment indices created by the EBRD. We again interact these variables with

\footnotetext{
${ }^{34}$ Interestingly, Borisova and Megginson (2011) find that the cost of debt rises with percentage privatized, which might suggest that financially dependent firms might be relatively worse off when privatized, but they also report costs of debt fall with full privatization and with faster privatization, implying that the higher debt costs may result from uncertainty about control during the privatization process. Costs of debt may rise with privatization, as they point out, because of the loss of implicit state guarantees that creditors to state-owned enterprises will be bailed out. ${ }^{35}$ In an industry-level study, Knyazeva, Knyazeva, and Stiglitz (2013) find that privatization performance effects are stronger where property and contracting rights protection is greater, and Brown, Earle, and Gehlbach (2009) find an association across Russian regions between privatization effects and the size of the regional bureaucracy.
} 
the domestic privatization dummy to measure the heterogeneity in privatization effectiveness along these dimensions.

Figure 13 (Table B9) presents the dependence of privatization effects on the macroeconomic environment, measured alternatively by GDP, CPI, and 3-digit industrial output growth. The estimated coefficients represent the effect of one standard deviation in the growth of GDP, CPI, and industrial output, respectively. GDP growth is estimated to raise the effect of privatization in five of six specifications. The LP effects are similar in magnitude in both the FE and FE\&FT specifications, implying that a one standard deviation increase in GDP growth adds about three percent to the operating efficiency effect. The Output results are inconsistent, however, with the FE showing a negative impact of GDP growth while the FE\&FT is positive; both are statistically significant.

The results for CPI inflation are also strongly associated with privatization effectiveness. Except for the FE specification for Output where the coefficient is positive but statistically insignificant, the estimates imply more than a percent-for-percent loss in the privatization effect on firm performance under higher inflation conditions.

Figure 13 also investigates the effects of growth at the 3-digit industry rather than the economy level, finding a strong relationship for all specifications and outcome variables. A one standard deviation increase in industrial output growth raises the privatization effect by about two percent for ROS and about 4 percent for LP and Output. Therefore, the results suggest that the macroeconomic environment complements, rather than substitutes for privatization; the more stable the economy is and the faster it grows, the more privatization raises firm performance.

Finally, we examine how the institutional environment influences privatization effectiveness. To do this we construct an average of the indices created by the EBRD measuring 
different institutional arrangements: price liberalization, international trade and foreign exchange system, competition policy, financial sector reform, and overall infrastructure reform. We standardize this average index so the standard deviation $=1$. Interacting it with the domestic privatization dummy leads to the results shown in Figure 14 (Table B10). In all specifications, the estimated coefficients are positive, statistically significant, and economically meaningful. A one-standard-deviation improvement in the business environment is estimated to raise the privatization effect on LP by 7-9 percent, ROS by 3-4 percent, and Output by 5-6 percent. The results thus imply a strong complementarity between privatization and the institutional environment.

\section{Conclusions}

A fundamental question for both business performance and economic policy is whether it matters if a firm is state or privately owned. In early theoretical research, Sappington and Stiglitz (1987) developed a model of public vs. private ownership assuming a welfaremaximizing government with imperfect information, while Shleifer and Vishny (1994) and Bocyko et al. (1996) analyzed theoretical models where political influences on firm behavior are reduced under private ownership. Hart et al.'s (1997) theoretical model suggests that private

owners have greater incentives to pursue investment to innovate and reduce costs. Until recently, however, too little data existed on ownership changes and their consequences to shed light on their importance to firm performance. Moreover, while we have seen a rush of empirical studies on privatization and firm performance, most have suffered from data limitations. Most use data from single countries and very short time periods, and nearly all have focused on estimating an average effect. The heterogeneity of results across studies may arise from 
differences in data quality, in dependent variable, and in estimation method, as well as in the time period and the country investigated.

This paper contributes to the literature by providing a first large-scale study examining heterogeneity in privatization effects using the large panel data sets and econometric methods that have become the norm in this research. The data are very similar across the five countries with a total of about 70,000 firms, half of which were privatized. The regressions use a common set of dependent variables and estimation methods. The data show considerable variation both across countries and over time in relevant factors that may influence the effectiveness of privatization at raising firm performance.

We find average privatization effects that are positive and statistically and economically significant in all our specifications and for all of our firm performance measures. We also find substantial differences in the estimated effects across countries and time periods, with a range from zero (or negative but small) to around 0.15 , depending on method and outcome variable. These differences do not appear to be artifacts of data construction, sample coverage, or misreporting biases. Our analysis of heterogeneity confirms previous findings regarding substantially stronger effects when the new private owner is a foreign rather than domestic investor. Among domestic privatizations, the results also confirm stronger effects when a larger fraction of the shares is privatized. Indeed, our results show roughly double the impact for a 100 percent privatization compared to majority but less than 100 percent domestic ownership. They also show that domestic privatization with a minority of shares may generate little or no performance improvement. Among domestic privatization methods, our results imply the largest impact from outside domestic investors, followed by MEBO privatizations (in Hungary and Romania, where these can be distinguished), and by mass/voucher privatization. We do not find 
consistent evidence for a positive additional effect of stock exchange listing, although this result should be interpreted bearing in mind both the small sample size available for this analysis and the general weaknesses of organized exchanges and other financial institutions in the countries in our database.

Concerning firm characteristics, the analysis suggests that privatization raises performance more in weaker and smaller SOEs, while results for technology use, financial dependence, and capital intensity are less conclusive. We find strong effects associated with both aggregate (GDP) and market (3-digit industry) growth, suggesting that private ownership advantages may lie more in exploiting opportunities than in cost cutting. The relationship with inflation is also strong, a finding consistent with the importance of clear price signals for private ownership effectiveness. Finally, we find the privatization effect increases with the quality of the institutional environment such that privatization and improving institutions are complementary policies rather than substitutes in their effects on firm performance.

The magnitudes of the estimated effects are substantial for several of these factors. Referring to the more stringent FE\&FT specification, for instance, the foreign-domestic differential is 0.09 for Labor Productivity and 0.17 for Output, and the 100 percent versus minority privatization is estimated at $0.06-0.13$, depending on dependent variable. A standard deviation change in firm quality (measured as pre-privatization relative productivity) induces as much as a 0.06 differential, while standard deviation improvements in macroeconomic stability/growth and in the institutional environment create differentials up to 0.09 . Thus, the analysis shows that these factors may account for much of the range of differences in estimated privatization effects across countries and time periods. 
Lest anyone think the firm ownership-performance question is relevant only to the $20^{\text {th }}$ century, we are reminded that the large-scale privatizations of the 1990s produce ongoing economic performance implications in the countries carrying out these programs. Moreover, the governments in these countries still hold large numbers of SOEs, which we exploit as a control group in our estimate strategy. State ownership of assets and operating enterprises also persists in the wider world. The Economist (2014) for instance, quotes an estimated value of $\$ 4$ trillion for all state property and advocates renewed attention to privatization almost everywhere. ${ }^{36}$ While some of the motivation for privatization stems from the potential sales revenue for strapped government budgets, the economic performance effects, and the conditions under which larger performance gains may be realized, are relevant for planning this "new wave" of privatization.

\footnotetext{
${ }^{36}$ Borisova et al. (2014) and Megginson and Fotak (2014) are recent studies of government ownership.
} 


\section{References}

Aghion, Philippe and Olivier Blanchard, 1996, On insider privatization, European Economic Review 40, 759-766.

Arellano, Manuel, 1987, Computing robust standard errors for within-groups estimators, Oxford Bulletin of Economics and Statistics 49, 431-434.

Bai, Chong-En, Jiangyong Lu, and Zhigang Tao, 2009, How does privatization work in China? Journal of Comparative Economics 37, 453-470.

Barberis, Nicholas, Maxim Boycko, Andrei Shleifer, and Natalia Tsukanova, 1996, How does privatization work? Evidence from the Russian shops, Journal of Political Economy, 104, 764790.

Bartel, Ann P., and Ann E. Harrison, 2005, Ownership versus environment: disentangling the sources of public-sector inefficiency, Review of Economics and Statistics 87(1), 135-147.

Bena, Jan, and Peter Ondko, 2012, Financial development and the allocation of external finance, Journal of Empirical Finance, Volume 19(1), 1-25.

Berger, Allen N., Iftekhar Hasan, and Mingming Zhou, 2009, Bank ownership and efficiency in China: what will happen in the world's largest nation? Journal of Banking and Finance 33, 113130.

Black, Bernard, Reinier Kraakman, and Anna Tarassova, 2000, What went wrong with Russian privatization? Stanford Law Review 52, 1-84.

Blanchard, Olivier, Rudiger Dornbusch, Paul Krugman, Richard Layard, and Lawrence Summers, 1991, Reform in Eastern Europe, (MIT Press, Cambridge, MA).

Bonin, John P., Derek C. Jones, and Louis Putterman, 1993, Theoretical and empirical studies of producer cooperatives: will ever the twain meet? Journal of Economic Literature 31, 1290-1320. 
Borisova, Ginka, Veljto Fotak, Kateryna Holland, and William L. Megginson, 2014, Government ownership and the cost of debt: Evidence from government investments in publiclytraded firms, working paper.

Borisova, Ginka, and William M. Megginson, 2011, Does government ownership affect the cost of debt? Evidence from privatization. Review of Financial Studies 24, 2693-2737.

Bortolotti, Bernardo, and Mara Faccio, 2009, Government control of privatized firms. Review of Financial Studies 22, 2907-2939.

Boubakri, Narjess, and Jean-Claude Cosset, 1998, The financial and operating performance of newly privatized firms: evidence from developing countries, Journal of Finance 53, 1081-1110. Boubakri, Narjess, Jean-Claude Cosset, and Omrane Guedhami, 2005, Liberalization, corporate governance and the performance of privatized firms in developing countries, Journal of Corporate Finance 11, 767-790.

Boycko, Maxim, Andrei Shleifer, and Robert W.Vishny, 1995, Privatizing Russia (MIT Press, Cambridge, MA).

Boycko, Maxim, Andrei Shleifer, and Robert W.Vishny, 1996, A theory of privatisation, Economic Journal, 106, 309-319.

Brown, J. David, John S. Earle, and Scott Gehlbach, 2009, Helping hand or grabbing hand? State bureaucracy and privatization effectiveness, American Political Science Review 103, 264-283.

Brown, J. David, John S. Earle, and Scott Gehlbach, 2013, Privatization, in Michael Alexeev and Shlomo Weber, eds: The Oxford Handbook of the Russian Economy, (Oxford, New York, Oxford University Press). 
Brown, J. David, John S. Earle, and Álmos Telegdy, 2006, The productivity effects of privatization: longitudinal estimates from Hungary, Romania, Russia, and Ukraine, Journal of Political Economy 114, 61-99.

Brown, J. David, John S. Earle, and Álmos Telegdy, 2010, Employment and wage effects of privatisation: evidence from Hungary, Romania, Russia, and Ukraine, The Economic Journal, $120,683-708$.

Brown, J. David, John S. Earle, Hanna Vakhitova, and Vitaliy Zheka, 2012, Innovation, adoption, ownership and productivity: evidence from Ukraine, in Tilman Brück and Hartmut Lehmann, eds: In the grip of transition: economic and social consequences of restructuring in Russia and Ukraine, (Houndmills, Basingstoke, Hampshire, Palgrave Macmillan).

Burkart, Mike, Denis Gromb, and Fausto Panunzi, 1998, Why higher takeover premia protect minority shareholders, Journal of Political Economy, 106, 172-204.

Caves, Douglas W., and Laurits R. Christensen, 1980, The relative efficiency of public and private firms in a competitive environment: the case of Canadian railroads, Journal of Political Economy 88, 958-976.

Claessens, Stijn, and Simeon Djankov, 2002, Privatization benefits in Eastern Europe, Journal of Public Economics 83, 307-324.

Demsetz, Harold, and Kenneth Lehn, 1985, The structure of corporate ownership: causes and consequences, Journal of Political Economy 93, 1155-1177.

Dinc, I. Serdar, and Nandini Gupta, 2011, The decision to privatize: finance and politics, Journal of Finance 66, 241-270.

Djankov, Simeon, and Peter Murrell, 2002, Enterprise restructuring in transition: a quantitative survey, Journal of Economic Literature 40, 739-792. 
D’Souza, Juliet, and William L. Megginson, 1999, The financial and operating performance of privatized firms during the 1990s, Journal of Finance 54, 1397-1438.

D’Souza, Juliet, William L. Megginson, and Robert Nash, 2005, Effect of institutional and firmspecific characteristics on post-privatization performance: evidence from developed countries, Journal of Corporate Finance 11, 747-766.

Earle, John S., Roman Frydman, Andrzej Rapaczynski, and Joel Turkewitz, 1994, Small Privatization: The Transformation of Retail Trade and Consumer Services in the Czech Republic, Hungary, and Poland, CEU Press, London.

Earle, John S. and Saul Estrin, 1996, Employee ownership in transition, in R. Frydman et al., eds.: Corporate Governance in Central Europe and Russia, (World Bank and Central European University Press).

Earle, John S. and Álmos Telegdy, 1998, The results of 'mass privatization' in Romania: a first empirical study, Economics of Transition 6, 313-332.

Earle, John S. and Álmos Telegdy, 2002, 'Privatization methods and productivity effects in Romanian industrial enterprises, Journal of Comparative Economics 30, 657-682.

Economist, 2014, Selling out the store, 410(8869), 18-21.

Ellerman, David, 1993, Management and employee buy-outs in Central and Eastern Europe: introduction, in David Ellerman, ed.: Management and Employee Buy-Outs as a Technique of Privatization (Central and Eastern European Privatization Network, Ljubljana).

Estrin, Saul, Jan Hanousek, Evzen Kocenda, and Jan Svejnar, 2009, The effects of privatization and ownership in transition economies, Journal of Economic Literature 47, 699-728. 
Frydman, Roman, Cheryl W. Gray, Marek Hessel, and Andrzej Rapaczynski, 1999, When does privatization work? The impact of private ownership on corporate performance in the transition economies, Quarterly Journal of Economics 114, 1153-1192.

Frydman, Roman, and Andrzej Rapaczynski, 1994, Privatization in Eastern Europe: Is the State Withering Away? (Central European University Press in cooperation with Oxford University Press).

Frydman, Roman, Andrzej Rapaczynski, John S. Earle, et al., 1993a, The Privatization Process in Central Europe, (Central European University Press, London).

Frydman, Roman, Andrzej Rapaczynski, John S. Earle, et al., 1993b, The Privatization Process in Russia, Ukraine, and the Baltic States, (Central European University Press, London).

Grigorian, David, 2000, Ownership and performance of Lithuanian enterprises, World Bank Policy Research Paper No. 2343.

Gupta, Nandini, 2005, Partial privatization and firm performance, Journal of Finance 60, 9871015.

Gupta, Nandini, John C. Ham, and Jan Svejnar, 2008, Priorities and sequencing in privatization: Theory and evidence from the Czech Republic, European Economic Review 52, 183-208. Hansmann, Henry, 1990, When does worker ownership work? ESOPs, law firms,codetermination, and economic democracy, Yale Law Journal 99, 1749-1816.

Hart, Oliver, Andrei Shleifer, and Robert W. Vishny, 1997, The proper scope of government: theory and an application to prisons, Quarterly Journal of Economics, 112, 1127-1161.

Heckman, James, and V. Joseph Hotz, 1989, Choosing among alternative nonexperimental methods for estimating the impact of social programs: the case of manpower training, Journal of the American Statistical Association 84, 862-874. 
Heckman, James, Robert LaLonde, and Jeffrey Smith, 1999, The economics and econometrics of active labor market programs, in Orley Ashenfelter and David Card, eds.: Handbook of Labor Economics, Vol. 3A (Elsevier, Amsterdam).

Jiang, Guohua, Heng Yue, and Longkai Zhao, 2009, A re-examination of China's share issue privatization, Journal of Banking and Finance 33, 2322-2332.

Knyazeva, Anzhela, Diana Knyazeva, and Joseph Stiglitz, 2009, Ownership changes and access to external financing, Journal of Banking and Finance, 33, 1804-1816.

Knyazeva, Anzhela, Diana Knyazeva, and Joseph Stiglitz, 2013, Ownership change, institutional development and performance, Journal of Banking and Finance, 37, 2605-2627.

Kornai, Janos, 1994, Transformational recession: The main causes, Journal of Comparative Economics, 19, 39-63.

Kornai, János, 2000, Ten years after 'The Road to a Free Economy’ the author's self-evaluation, Economic Systems 24, 353-359.

La Porta, Rafael, Florencio Lopez-De-Silanes, and Andrei Shleifer, 1998, Law and finance, The Journal of Political Economy 106, 1113-1155.

Li, Wei, and Lixin Colin $\mathrm{Xu}, 2004$, The impact of privatization and competition in the telecommunications sector around the world, Journal of Law and Economics 47(2), 395-430.

Lipton, David, and Jeffrey Sachs, 1990, Privatization in Eastern Europe: the case of Poland, Brookings Papers on Economic Activity 21, 293-342.

Megginson, William L., Robert C. Nash, and Matthias van Randenborgh, 1994, The financial and operating performance of newly privatized firms: an international empirical analysis, Journal of Finance 49, 403-452. 
Megginson, William L., and Jeffry M. Netter, 2001, From state to market: a survey of empirical studies on privatization, Journal of Economic Literature 39, 321-389.

Megginson, William L., and Veljko Fotak, 2014, Rise of the fiduciary state: A survey of sovereign wealth fund research, working paper.

Mygind, Niels, 1997, Employee ownership in the Baltic countries, in Milica Uvalic and Daniel Vaughan-Whitehead, eds.: Privatization Surprises in Transition Economies. EmployeeOwnership in Central and Eastern Europe (Edward Elgar, Cheltenham).

OECD, 2011, ISIC Rev. 3 Technology Intensity Definition, www.oecd.org/sti/ind/48350231.pdf, accessed July 3, 2014.

Roland, Gérard, 2001, Ten years after ... transition and economics, IMF Staff Papers 48, 29-52.

Sappington, David, and Joseph Stiglitz, 1987, Privatization, information and incentives, Journal of Policy Analysis and Management 6, 567-582.

Shleifer, Andrei, and Robert W. Vishny, 1994, Politicians and firms, Quarterly Journal of Economics 109, 995-1025.

Spicer, Andrew, Gerald A. McDermott, and Bruce Kogut, 2000, Entrepreneurship and privatization in Central Europe: the tenuous balance between destruction and creation, The Academy of Management Review 25, 630-649.

State Statistics Service of Ukraine, 2014, www.ukrstat.gov.ua, accessed July 3, 2014.

Stiglitz, Joseph, 1999, Whither reform? Ten years of the transition, in Boris Pleskovic and Joseph Stiglitz, eds.: Annual World Bank Conference on Economic Development, (World Bank, Washington, DC).

Sun, Quian, and Wilson H.S. Tong, 2003, China share issue privatization: the extent of its success, Journal of Financial Economics 70, 183-222. 
Szentpéteri, Ádám, and Álmos Telegdy, 2010, Political selection of firms into privatization programs. Evidence from Romanian comprehensive data, Economics and Politics 22(3), 298328.

Weitzman, Martin L., 1993, How not to privatize, in Mario Baldassarri, Luigi Paganetto, and Edmund Phelps, eds.: Privatization Processes in Eastern Europe, (St. Martin's Press, New York).

Zhuravskaya, Ekaterina, 2007, Whither Russia? A review of Andrei Shleifer's A Normal Country, Journal of Economic Literature 45, 127-146. 
Figure 1: EBRD Reform Indicators

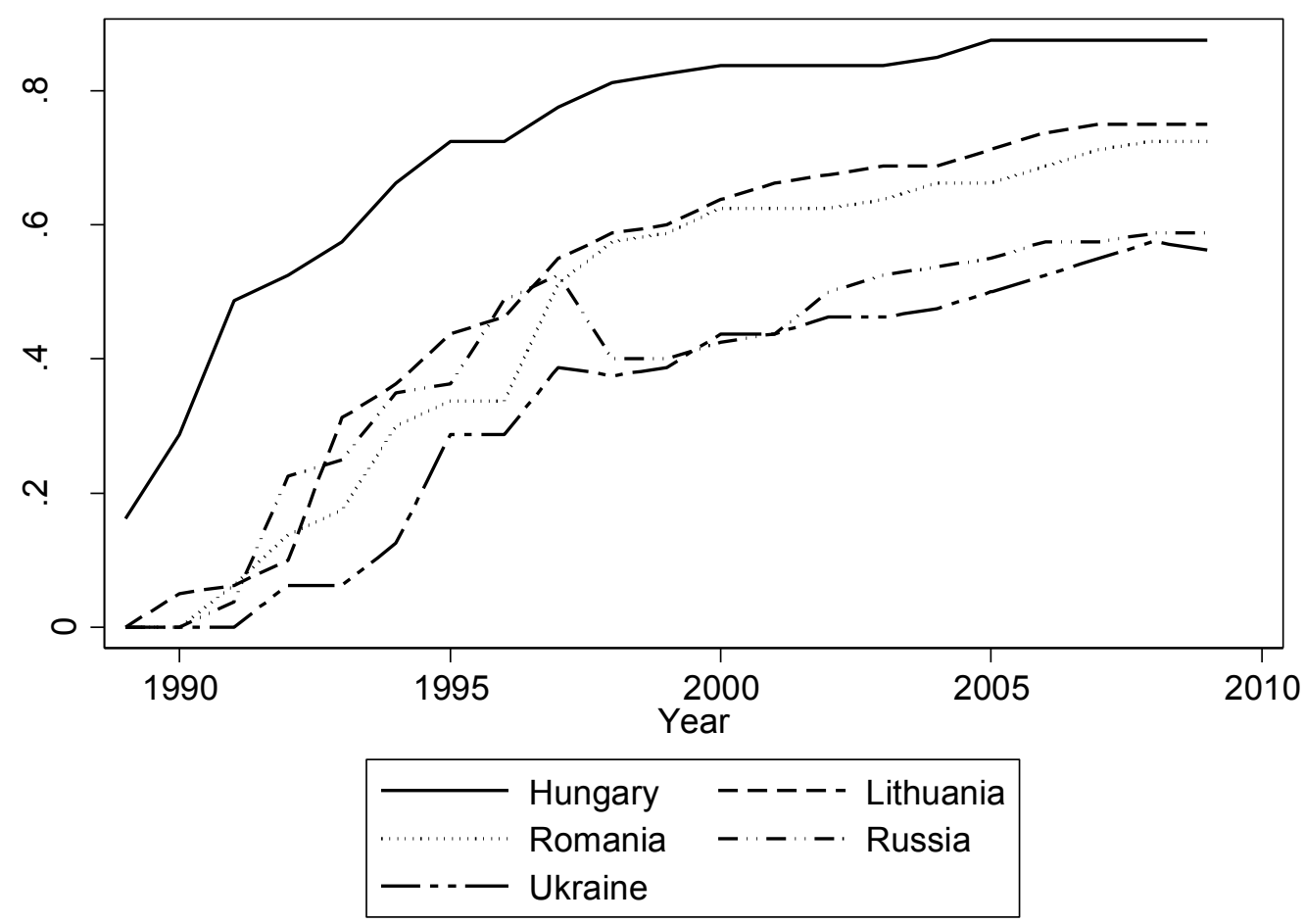

The EBRD publishes annual indicators for multiple dimensions of institutional reform on a scale between 1 and 4.33 , where 1 reflects central planning and 4.3 a market economy. Here we have averaged all the indices for each country-year and normalized them to a 0-1 scale. The methodology is described in Appendix 1.

Source of indicators: http://www.ebrd.com/what-we-do/economic-research-anddata/data/forecasts-macro-data-transition-indicators.html. 
Figure 2: The Evolution of Real GDP, by Country

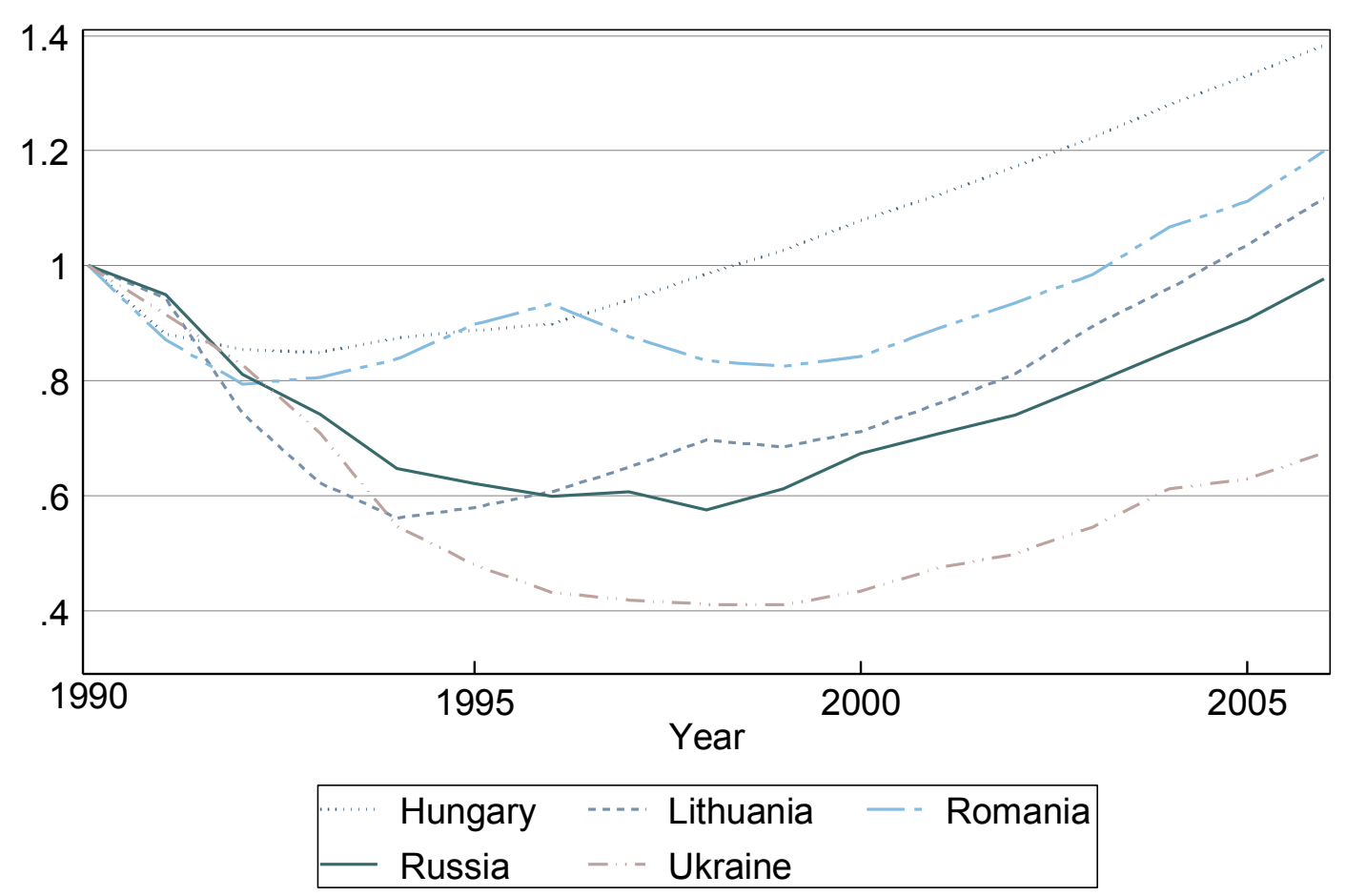

Source: World Bank website. 
Figure 3: Share of Privatized Firms in the Sample

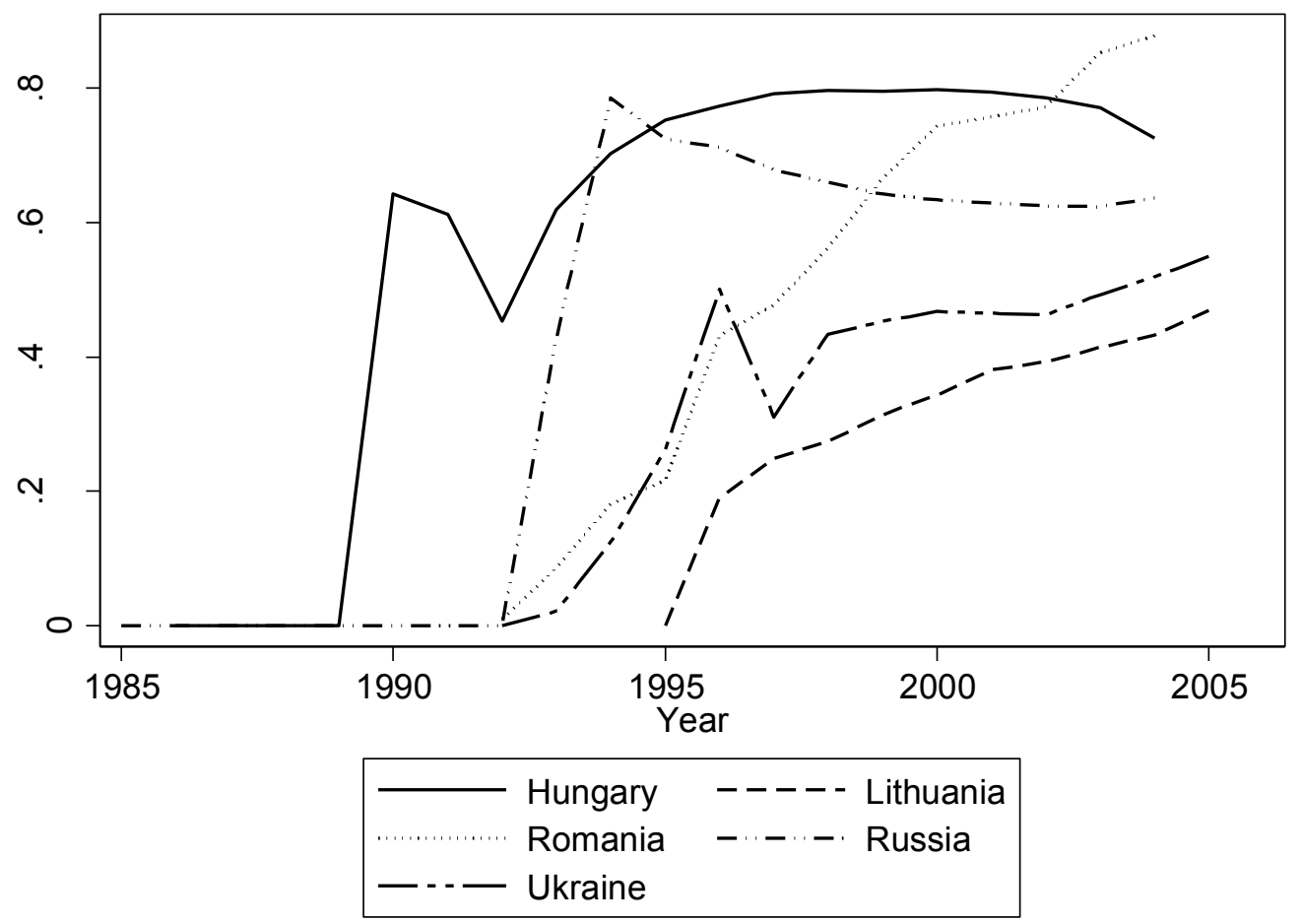

The graph plots the share of privatized firms (100\% and majority) for each country and year of the sample. Only firms entering the data as state-owned are included in the sample. Decreases in private share result from sample changes, not nationalizations. 
Table 1: Share of Firms Privatized as of 2005,

\section{Classified by Percentage Privatized and Methods of Privatization}

The table presents measures of the extent of privatization as of 2005 , by country. "Domestic" = privatized firms with domestic share larger than foreign share; "Foreign" = privatized firms which are not domestic. "100\% privatized" = domestic privatizations with 100 percent private shareholdings; "Majority" = domestic privatizations with majority private and minority state shareholdings; "Minority" = majority state-owned companies with minority domestic private shareholdings. "Investor" = domestic firms with majority of private shares obtained through direct sales; "MEBO" = domestic firms with majority of private shares obtained through management-employee buyouts; "Voucher" = domestic firms with majority of private shares obtained through voucher privatization. The classification by method is available only in Hungary and Romania. N.A.= Not available.

\begin{tabular}{lccccc}
\hline & Hungary & Lithuania & Romania & Russia & Ukraine \\
\hline Classified by Percent Privatized (including minority & domestic private) & & \\
All domestic, of which & 0.71 & 0.41 & 0.97 & 0.60 & 0.45 \\
100\% privatized & 0.63 & 0.31 & 0.68 & 0.40 & 0.32 \\
Majority & 0.02 & 0.01 & 0.19 & 0.20 & 0.07 \\
$\quad$ Minority & 0.06 & 0.09 & 0.10 & 0.00 & 0.06 \\
Foreign & 0.09 & 0.02 & 0.03 & 0.02 & 0.02 \\
\hline
\end{tabular}

Classified by Method of Privatization (only $100 \%$ and majority privatization)

$\begin{array}{llllll}\text { Domestic, of which } & 0.62 & 0.32 & 0.84 & 0.60 & 0.44 \\ \text { Investor } & 0.60 & \text { N. A. } & 0.34 & \text { N. A. } & \text { N. A. } \\ \text { MEBO } & 0.02 & \text { N. A. } & 0.31 & \text { N. A. } & \text { N. A. } \\ \quad \text { Voucher } & \text { N.A. } & \text { N. A. } & 0.19 & \text { N. A. } & \text { N. A. } \\ \text { Foreign } & 0.09 & 0.02 & 0.03 & 0.02 & 0.02\end{array}$




\section{Table 2: Number of Observations in Regressions by Ownership Type}

The table presents the number of firms and firm-years by country that enter the Output regressions. "State" = firms that are never majority-privatized. "Domestic" = privatized firms (with majority private shares) with domestic share larger than foreign share; "Foreign" = privatized firms which are not domestic. Most of these are majority-owned by foreign owners, but some of them also have minority foreign ownership. The few firms that changed their ownership status from domestic to foreign (or vice versa) during the post-privatization period are double-counted during the pre-privatization period.

\begin{tabular}{|c|c|c|c|c|c|c|}
\hline & \multicolumn{2}{|c|}{ State } & \multicolumn{2}{|c|}{ Privatized Domestic } & \multicolumn{2}{|c|}{ Privatized Foreign } \\
\hline & $\begin{array}{l}\text { Firm } \\
\text { years }\end{array}$ & Firms & $\begin{array}{l}\text { Firm } \\
\text { years }\end{array}$ & Firms & $\begin{array}{l}\text { Firm } \\
\text { years }\end{array}$ & Firms \\
\hline Hungary & 26,789 & 5,959 & 82,196 & 8,197 & 9,401 & 825 \\
\hline Lithuania & 8,938 & 1,347 & 6,974 & 804 & 494 & 47 \\
\hline Romania & 28,636 & 4,776 & 85,037 & 8,559 & 3,627 & 369 \\
\hline Russia & 60,678 & 7,895 & 162,477 & 12,007 & 3,646 & 263 \\
\hline Ukraine & 76,882 & 12,295 & 87,806 & 7,955 & 2,267 & 172 \\
\hline Total & 201,923 & 32,272 & 424,490 & 37,522 & 19,435 & 1,676 \\
\hline
\end{tabular}


Table 3: Descriptive Statistics for Variables Used in the Construction of Dependent Variables

The table presents the average values (standard deviations) of the dependent variables and the variables used in their construction for each country in the sample. The definitions of the variables are in Table A1. Financial variables are deflated by GDP deflators and converted to 1,000 USD using 2005 average exchange rates.

\begin{tabular}{cccccc}
\hline & Hungary & Lithuania & Romania & Russia & Ukraine \\
\hline Dependent variables & & & & \\
Return on Sales & -0.03 & -0.07 & -0.08 & 0.09 & 0.02 \\
& $(0.46)$ & $(0.47)$ & $(0.59)$ & $(0.50)$ & $(0.67)$ \\
Labor Productivity & 83.6 & 24.6 & 28.5 & 23.5 & 8.0 \\
& $(531)$ & $(95)$ & $(200)$ & $(130)$ & $(45)$ \\
Sales (Output) & 17208 & 2897 & 8376 & 21722 & 5190 \\
& $(90,894)$ & $(34,762)$ & $(110,161)$ & $(128,887)$ & $(43,107)$ \\
\hline Variables used in the construction of dependent variables & & \\
Net income & 656 & 109 & 201 & 3557 & 761 \\
& $(9,825)$ & $(1,876)$ & $(6,218)$ & $(44,183)$ & $(10,383)$ \\
Employment & 267 & 107 & 359 & 679 & 429 \\
& $(1,279)$ & $(496)$ & $(1,701)$ & $(2,074)$ & $(2,010)$ \\
\hline
\end{tabular}




\section{Table 4: Estimated Effects of Privatization on Firm Performance}

The table presents the estimated coefficients and standard errors (corrected for firm clustering) of a privatization dummy variable. The regressions are run on pooled samples from all countries. All regressions control for a full set of country-industry-year interactions; those labelled "FE" also include firm fixed effects and those labelled "FE\&FT" include both firm fixed effects and firm-specific trends. The regressions are weighted such that each country has an equal weight in each year. ${ }^{* *}=$ significant at 1 percent level.

\begin{tabular}{|c|c|c|c|}
\hline & $\begin{array}{c}\text { Return On } \\
\text { Sales } \\
\end{array}$ & $\begin{array}{c}\text { Labor } \\
\text { Productivity }\end{array}$ & Output \\
\hline & \multicolumn{3}{|c|}{$O L S$} \\
\hline Privatization & $\begin{array}{l}0.063 * * \\
(0.005)\end{array}$ & $\begin{array}{l}0.239 * * \\
(0.012)\end{array}$ & $\begin{array}{l}0.237 * * \\
(0.025)\end{array}$ \\
\hline $\mathrm{R}^{2}$ & 0.099 & 0.556 & 0.426 \\
\hline Privatization & $\begin{array}{l}0.052 * * \\
(0.005)\end{array}$ & $\begin{array}{c}F E \\
0.115^{* *} \\
(0.008)\end{array}$ & $\begin{array}{l}0.095 * * \\
(0.012)\end{array}$ \\
\hline $\mathrm{R}^{2}$ & 0.104 & 0.310 & 0.375 \\
\hline Privatization & $\begin{array}{l}0.030 * * \\
(0.006)\end{array}$ & $\begin{array}{c}F E \& F T \\
0.075^{* *} \\
(0.007)\end{array}$ & $\begin{array}{l}0.058 * * \\
(0.009)\end{array}$ \\
\hline $\mathrm{R}^{2}$ & 0.094 & 0.224 & 0.170 \\
\hline$N$ & 518,808 & 611,800 & 635,140 \\
\hline
\end{tabular}


Figure 4: Dynamic Effects of Privatization on Firm Performance
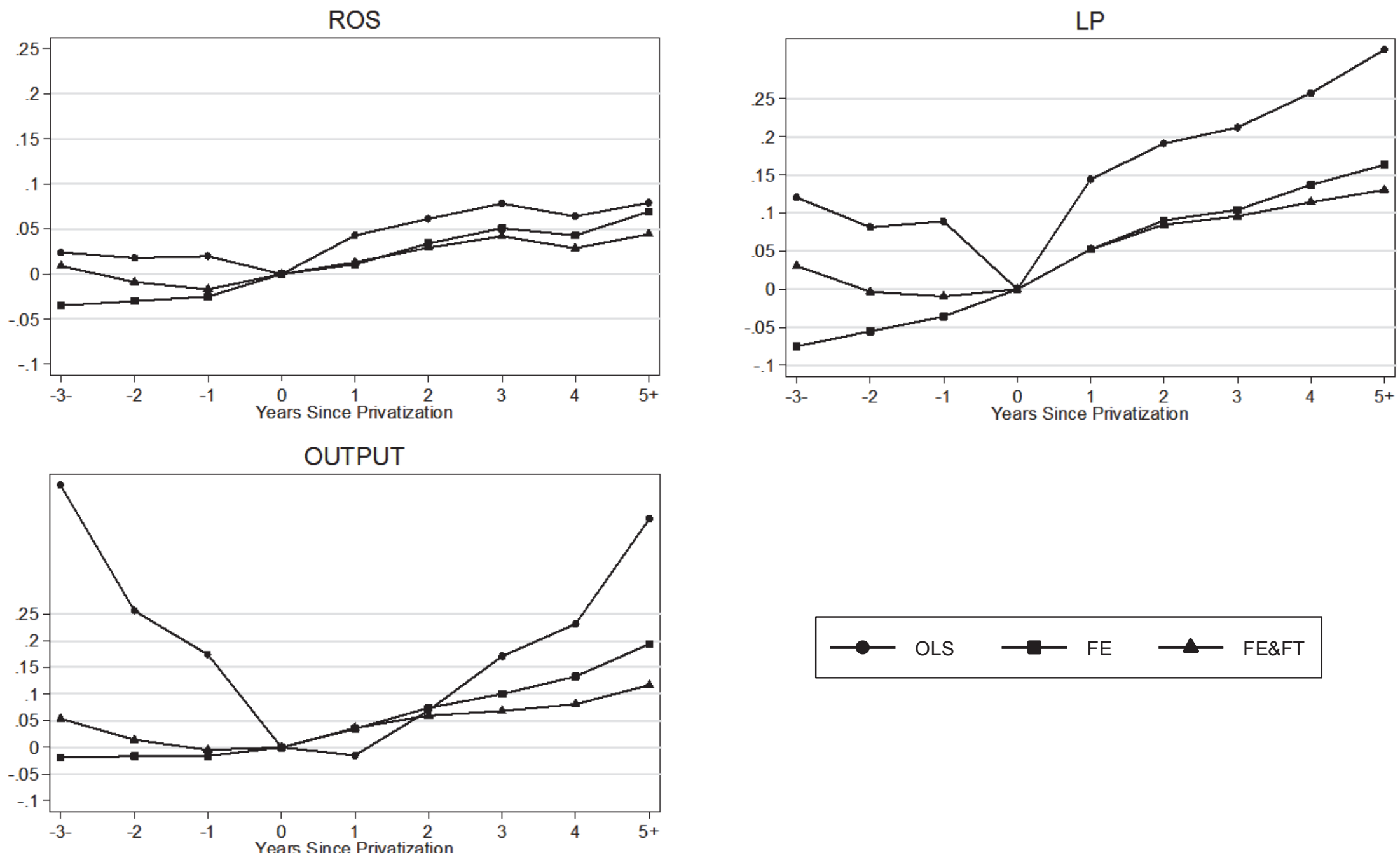

The graphs present regression coefficients of interactions between dummies for years before and after privatization and indicators for whether the firm is ever privatized. The privatization year (the omitted category) is " 0, " " $-3-"=3$ or more years before privatization, and " $5+$ " $=5$ or more years after privatization. ROS $=$ return on sales; LP = labor productivity; OUTPUT = sales. All regressions control for a full set of country-industry-year interactions; those labelled "FE" also include firm fixed effects and those labelled "FE\&FT" include both firm fixed effects and firm-specific trends. The coefficients and standard errors from the regressions are shown in Table B1. 


\section{Table 5: Pre-Program and Trend Break Test Results}

Pre-program test: $\mathrm{t}$-Statistics (P-values) for the coefficients showing the pre-privatization impact 1, 2, and 3 and more years before privatization. Trend-break test: F-test (P-values) for the equality of the difference in coefficients 1 and 3 or more years before-after privatization. The corresponding coefficients are graphed in Figure 4 and presented in Table B1. FE: firm fixed effects included in the regressions; FE\&FT: firm fixed effects and firm-level trends included in the regressions.

\begin{tabular}{|c|c|c|c|}
\hline & $\begin{array}{l}\text { Return On } \\
\text { Sales }\end{array}$ & $\begin{array}{c}\text { Labor } \\
\text { Productivity }\end{array}$ & Outpu \\
\hline Pre-Program Test & & $O L S$ & \\
\hline$\tau=-1$ & $\begin{array}{l}3.38 \\
(0.001)\end{array}$ & $\begin{array}{l}7.87 \\
(0.000)\end{array}$ & $\begin{array}{l}7.40 \\
(0.000)\end{array}$ \\
\hline$\tau=-2$ & $\begin{array}{l}2.62 \\
(0.009)\end{array}$ & $\begin{array}{l}6.54 \\
(0.000)\end{array}$ & $\begin{array}{l}9.56 \\
(0.000)\end{array}$ \\
\hline$\tau=-3$ & $\begin{array}{l}4.23 \\
(0.000)\end{array}$ & $\begin{array}{l}8.08 \\
(0.000)\end{array}$ & $\begin{array}{l}14.74 \\
(0.000)\end{array}$ \\
\hline$\tau=-1$ & $\begin{array}{l}-4.42 \\
(0.000)\end{array}$ & $\begin{array}{c}\quad F E \\
-5.90 \\
(0.000)\end{array}$ & $\begin{array}{l}-2.07 \\
(0.038)\end{array}$ \\
\hline$\tau=-2$ & $\begin{array}{l}-4.27 \\
(0.000)\end{array}$ & $\begin{array}{l}-6.66 \\
(0.000)\end{array}$ & $\begin{array}{l}-1.54 \\
(0.123)\end{array}$ \\
\hline$\tau=-3$ & $\begin{array}{l}-4.54 \\
(0.000)\end{array}$ & $\begin{array}{l}-6.60 \\
(0.000)\end{array}$ & $\begin{array}{l}-1.13 \\
(0.259)\end{array}$ \\
\hline$\tau=-1$ & $\begin{array}{l}-2.89 \\
(0.004)\end{array}$ & $\begin{array}{l}F E \& F T \\
-1.56 \\
(0.120)\end{array}$ & $\begin{array}{l}-0.74 \\
(0.458)\end{array}$ \\
\hline$\tau=-2$ & $\begin{array}{l}-1.08 \\
(0.279)\end{array}$ & $\begin{array}{l}-0.39 \\
(0.695)\end{array}$ & $\begin{array}{l}1.22 \\
(0.221)\end{array}$ \\
\hline$\tau=-3$ & $\begin{array}{c}0.84 \\
(0.401)\end{array}$ & $\begin{array}{l}2.40 \\
(0.016)\end{array}$ & $\begin{array}{l}3.40 \\
(0.001)\end{array}$ \\
\hline $\begin{array}{l}\text { Trend Break Test } \\
\text { ldo_1-ldo_3_= ldo3-ldo1 }\end{array}$ & $\begin{array}{c}6.47 \\
(0.002)\end{array}$ & $\begin{array}{c}\text { OLS } \\
31.02 \\
(0.000)\end{array}$ & $\begin{array}{l}51.57 \\
(0.000)\end{array}$ \\
\hline 1do_1-1do_3_=1do3-1do1 & $\begin{array}{c}7.84 \\
(0.005)\end{array}$ & $\begin{array}{c}F E \\
0.96 \\
(0.328)\end{array}$ & $\begin{array}{l}2.15 \\
(0.116)\end{array}$ \\
\hline 1do_1-1do_3_=1do3-1do1 & $\begin{array}{l}25.56 \\
(0.000)\end{array}$ & $\begin{array}{l}F E \& F T \\
52.05 \\
(0.000)\end{array}$ & $\begin{array}{l}44.13 \\
(0.000)\end{array}$ \\
\hline
\end{tabular}


Figure 5: Estimated Effect of Privatization by Country

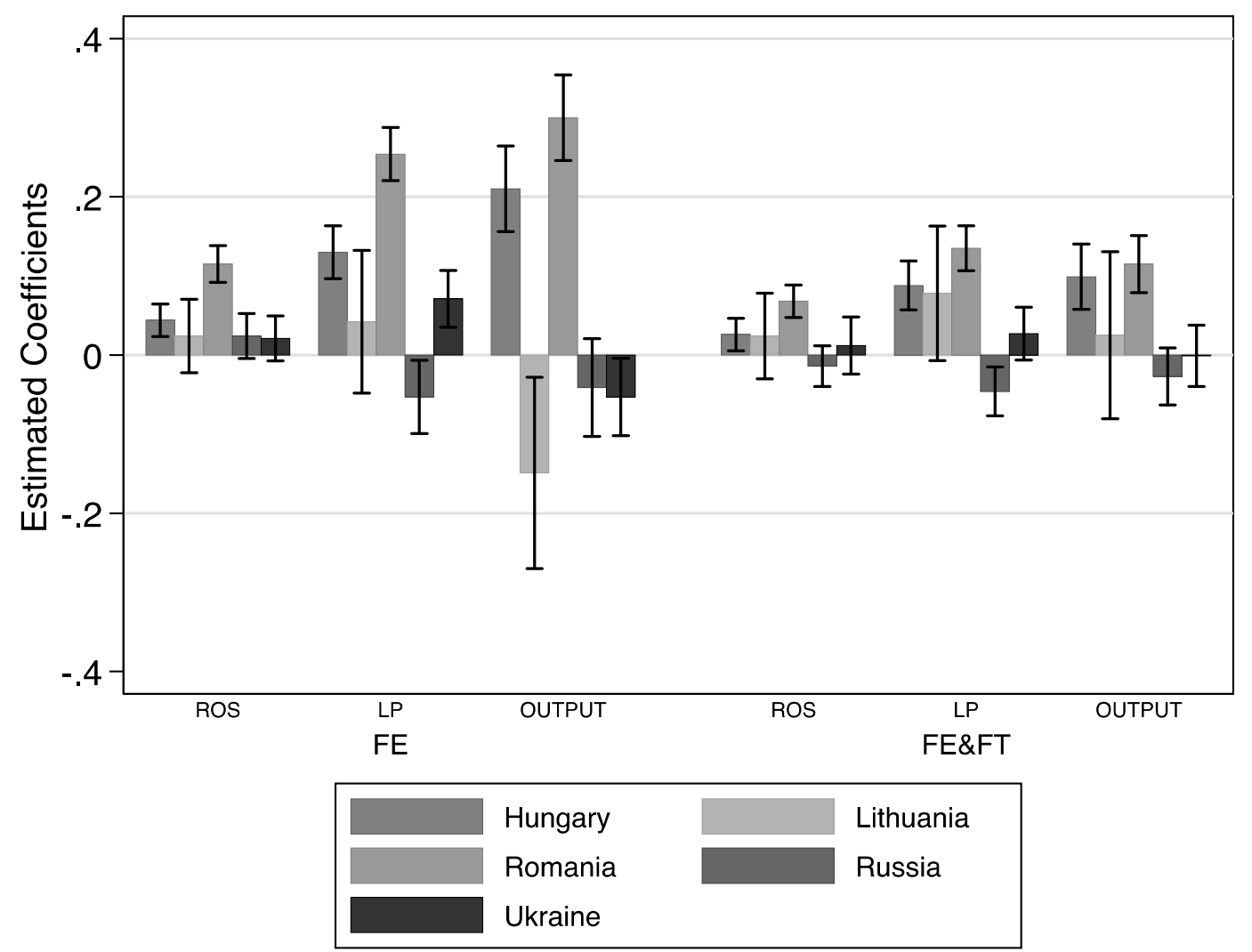

timated coefficients and $99 \%$ confidence intervals for separate regressions of a privatization dummy variable. $\mathrm{ROS}=$ return on sales; $\mathrm{LP}=$ labor productivity. All regressions control for a full set of country-industry-year interactions; those labelled "FE" also include firm fixed effects and those labelled "FE\&FT" include both firm fixed effects and firm-specific trends. The coefficients and standard errors from the regressions are shown in Table $\mathrm{C} 1$. 
Figure 6: Estimated Effect of Privatization by Time Period

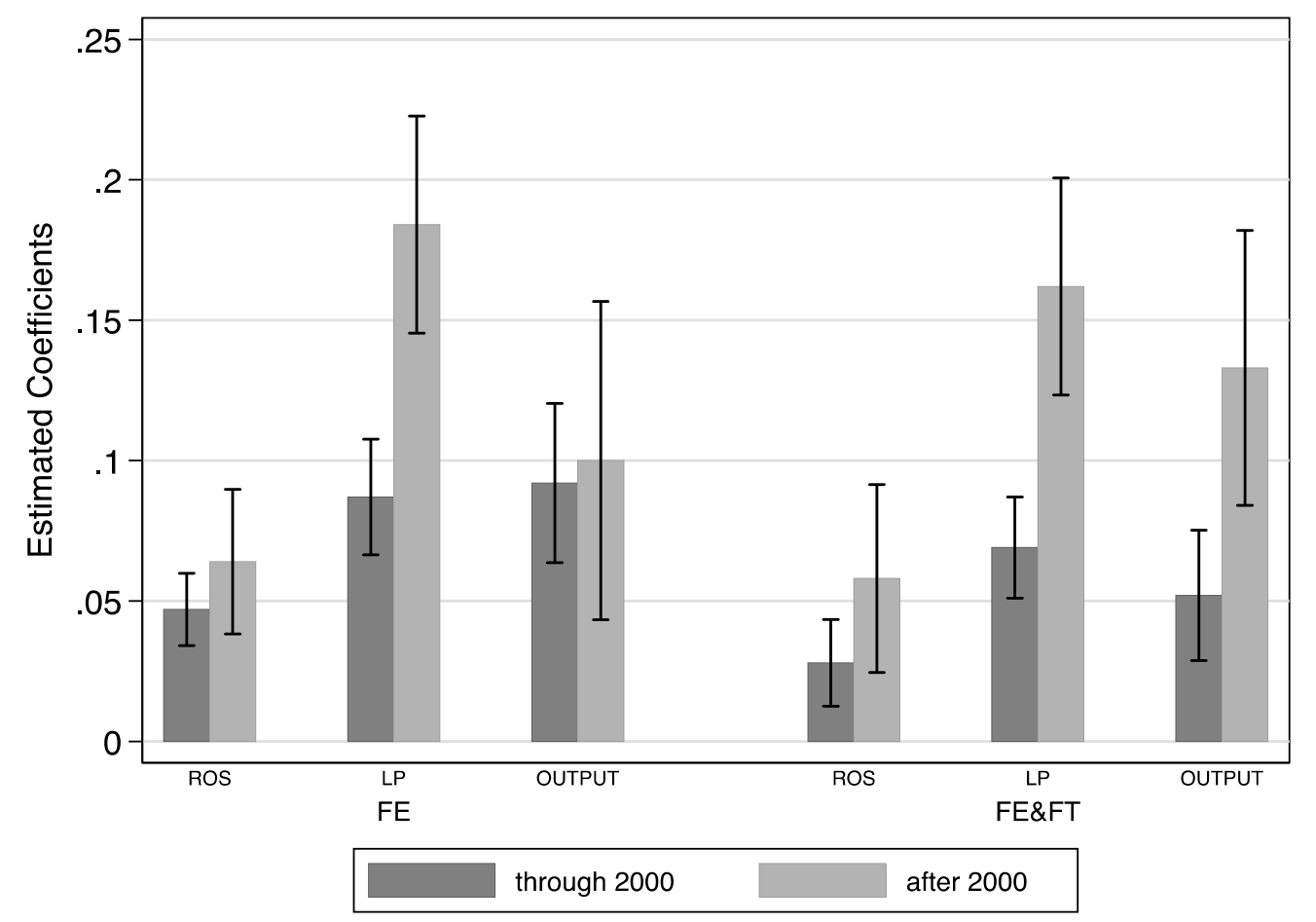

S

timated coefficients and 99\% confidence intervals for separate regressions containing interaction between a privatization dummy and a time period dummy. Time period dummy equals 1 for years up to 2000, and 0 for years 2001 onwards. All regressions control for a full set of country-industry-year interactions; those labeled "FE" also include firm fixed effects and those labeled "FE\&FT" include both firm fixed effects and firm-specific trends. The coefficients and standard errors from the regressions are shown in Table B2.

Figure 7: Estimated Effect of Privatization by Sector 

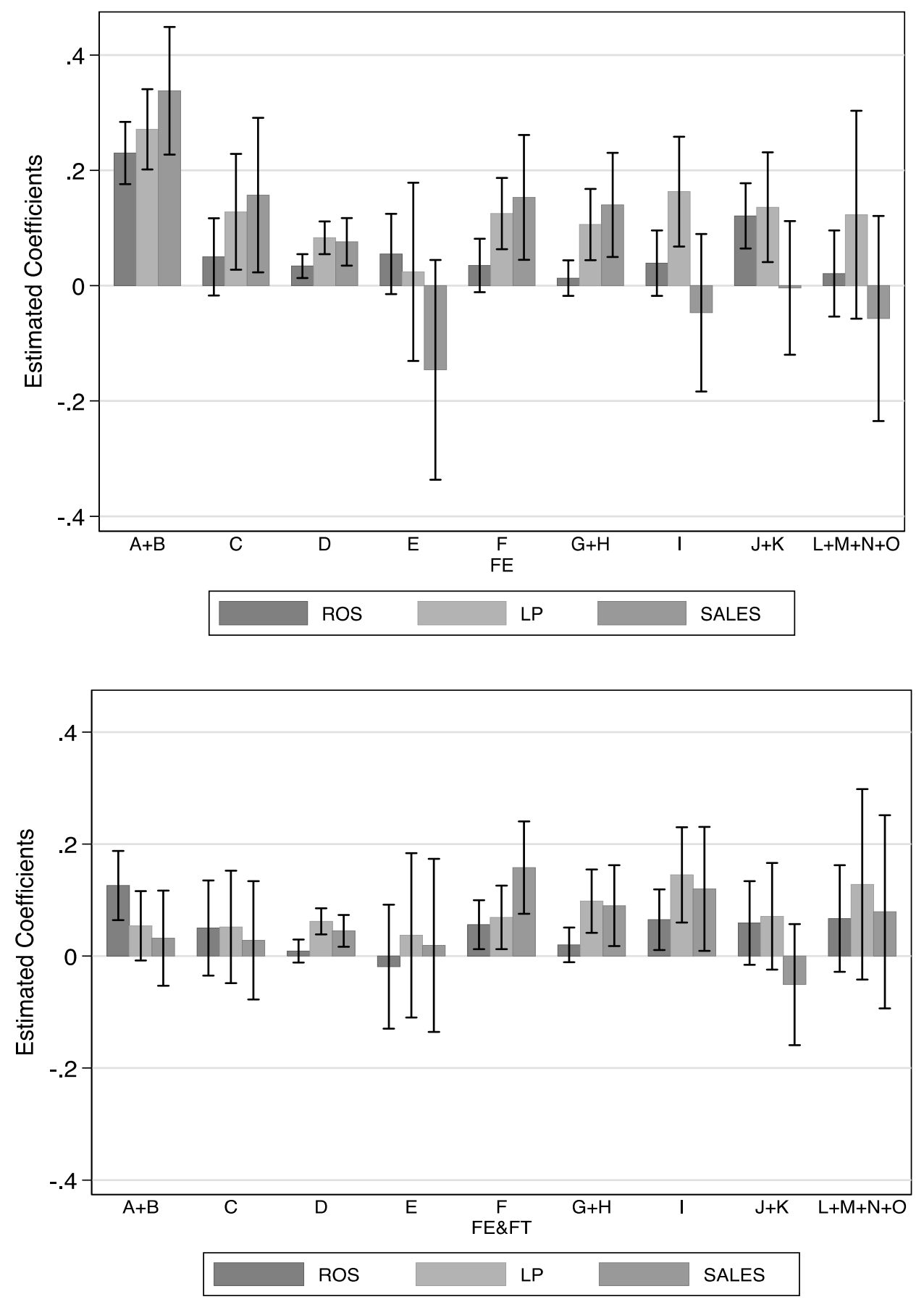

The figures present the estimated coefficients and $99 \%$ confidence intervals for separate regressions containing a privatization dummy. Each regression sample represents one sector group that includes one or more NACE 1.1 sectors. All regressions control for a full set of country-industry-year interactions; those labeled "FE" also include firm fixed effects and those labeled "FE\&FT" include both firm fixed effects and firm-specific trends. The coefficients and standard errors from the regressions are shown in Table B3. NACE sectors are defined as follows: $\mathrm{A}=$ Agriculture and forestry; $\mathrm{B}=$ Fishing; $\mathrm{C}=$ Mining; $\mathrm{D}=$ Manufacturing; $\mathrm{E}=$ Electricity, gas and water; $\mathrm{F}=$ Construction; $\mathrm{G}=$ Wholesale and retail trade; $\mathrm{H}=$ Hotels and restaurants; $\mathrm{I}=$ Transport and communication; $\mathrm{J}=$ Financial intermediation; $\mathrm{K}=$ Real estate; $\mathrm{L}=$ =Public administration and defense; $\mathrm{M}=$ Education; $\mathrm{N}=$ Health; $\mathrm{O}=$ Other service activities. 
Figure 8: Estimated Domestic and Foreign Privatization Effects

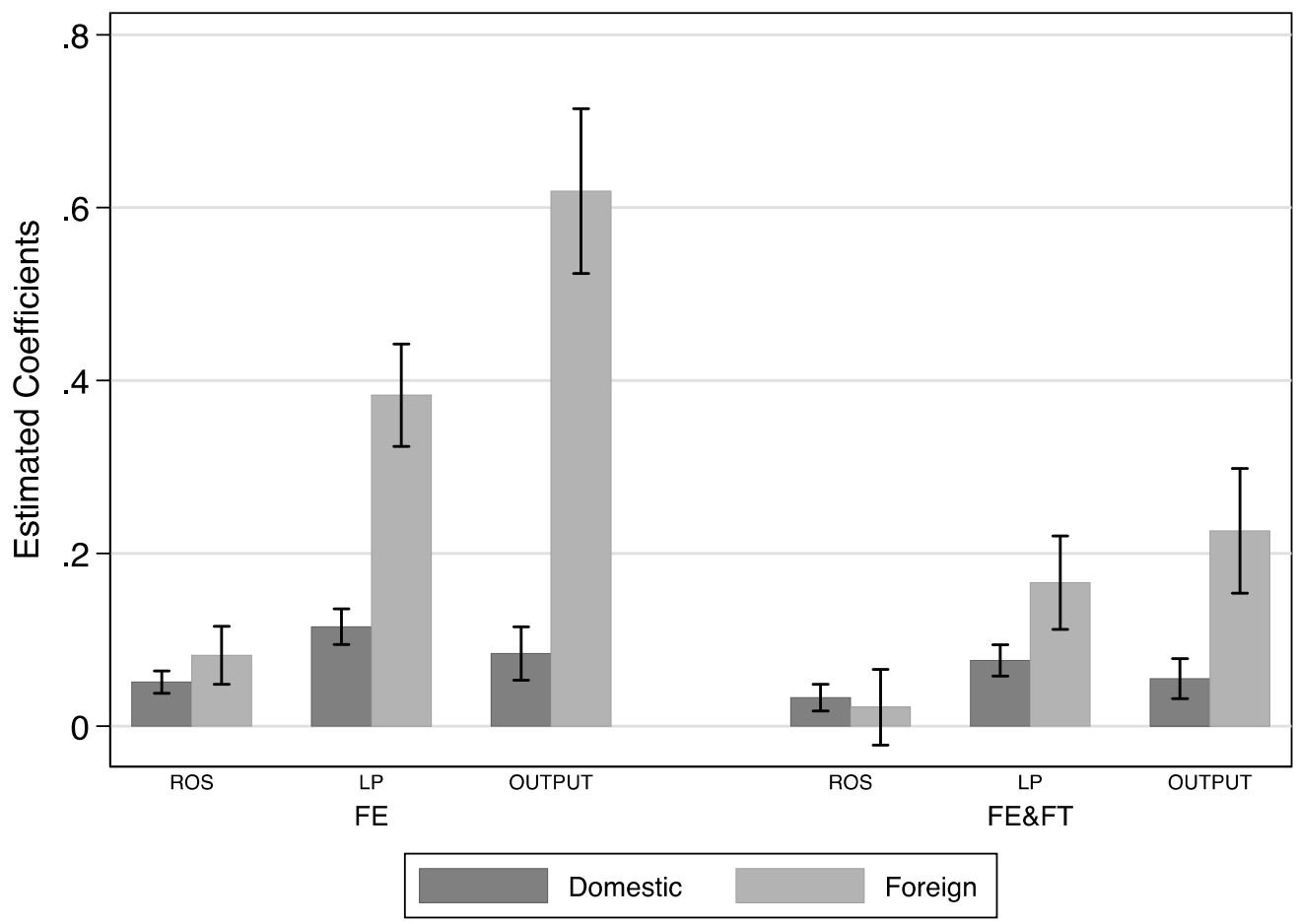

The figure presents the estimated coefficients and $99 \%$ confidence intervals for separate regressions containing a domestic and a foreign privatization dummy. The precise definitions of the domestic and foreign privatization dummies are in Table A1. All regressions control for a full set of country-industry-year interactions and a foreign dummy; those labelled "FE" also include firm fixed effects and those labelled "FE\&FT" include both firm fixed effects and firm-specific trends. The coefficients and standard errors from the regressions are shown in Table B4, and the country-specific estimates are shown in Table C3. 
Figure 9: Estimated Effects of Privatization by Method: MEBO, Voucher, and Domestic Sales in Hungary and Romania

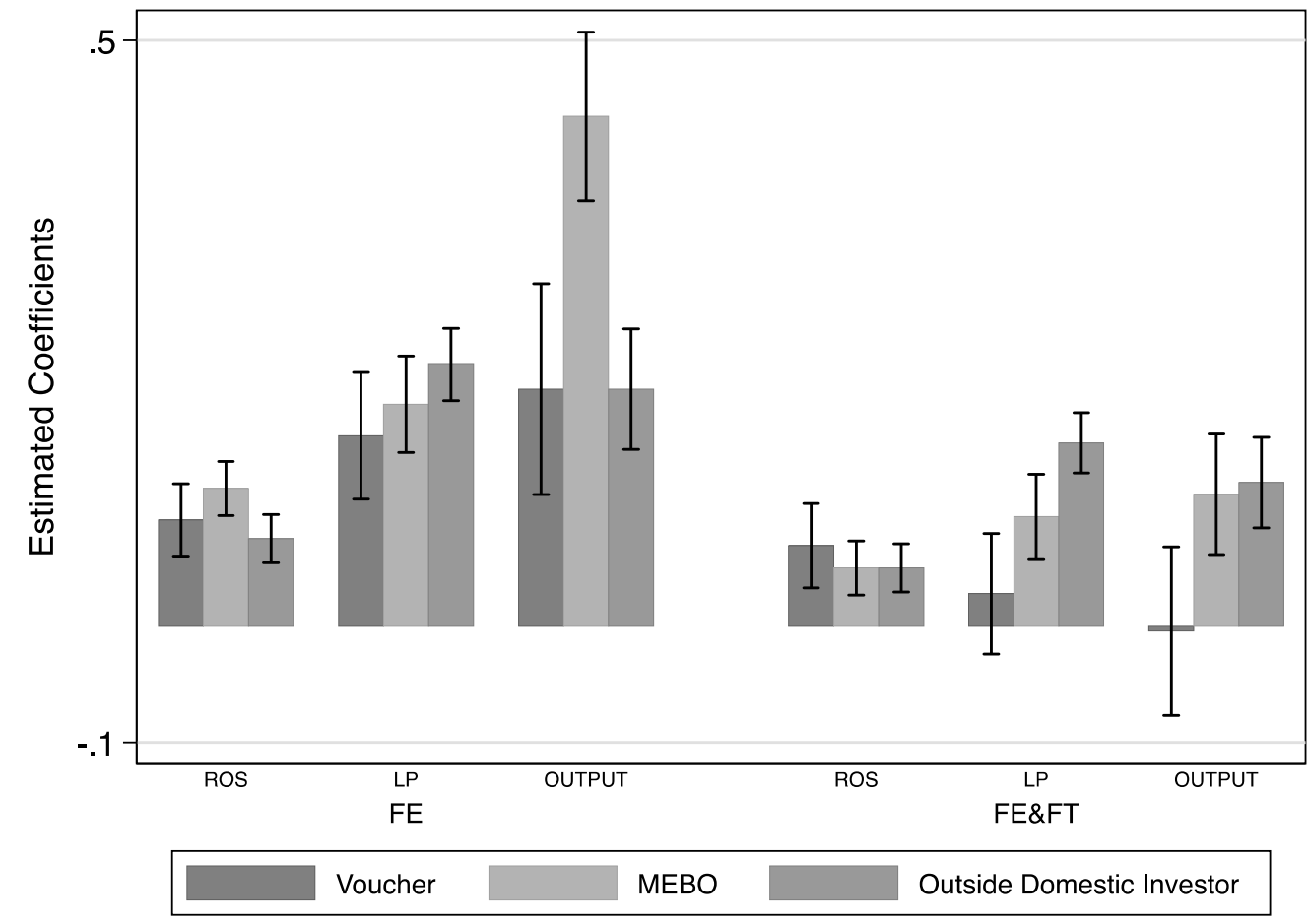

The figure presents the estimated coefficients and $99 \%$ confidence intervals for separate regressions containing sale privatizations to outside domestic investors, MEBO privatizations and Voucher privatizations in Hungary and Romania. All regressions control for a full set of country-industryyear interactions and a foreign dummy; those labelled "FE" also include firm fixed effects and those labelled "FE\&FT" include both firm fixed effects and firm-specific trends. The coefficients and standard errors from the regressions are shown in Table B5, and the country-specific estimates are shown in Table $\mathrm{C} 4$. 
Figure 10: Estimated Effects of Total, Majority, and Minority Privatizations

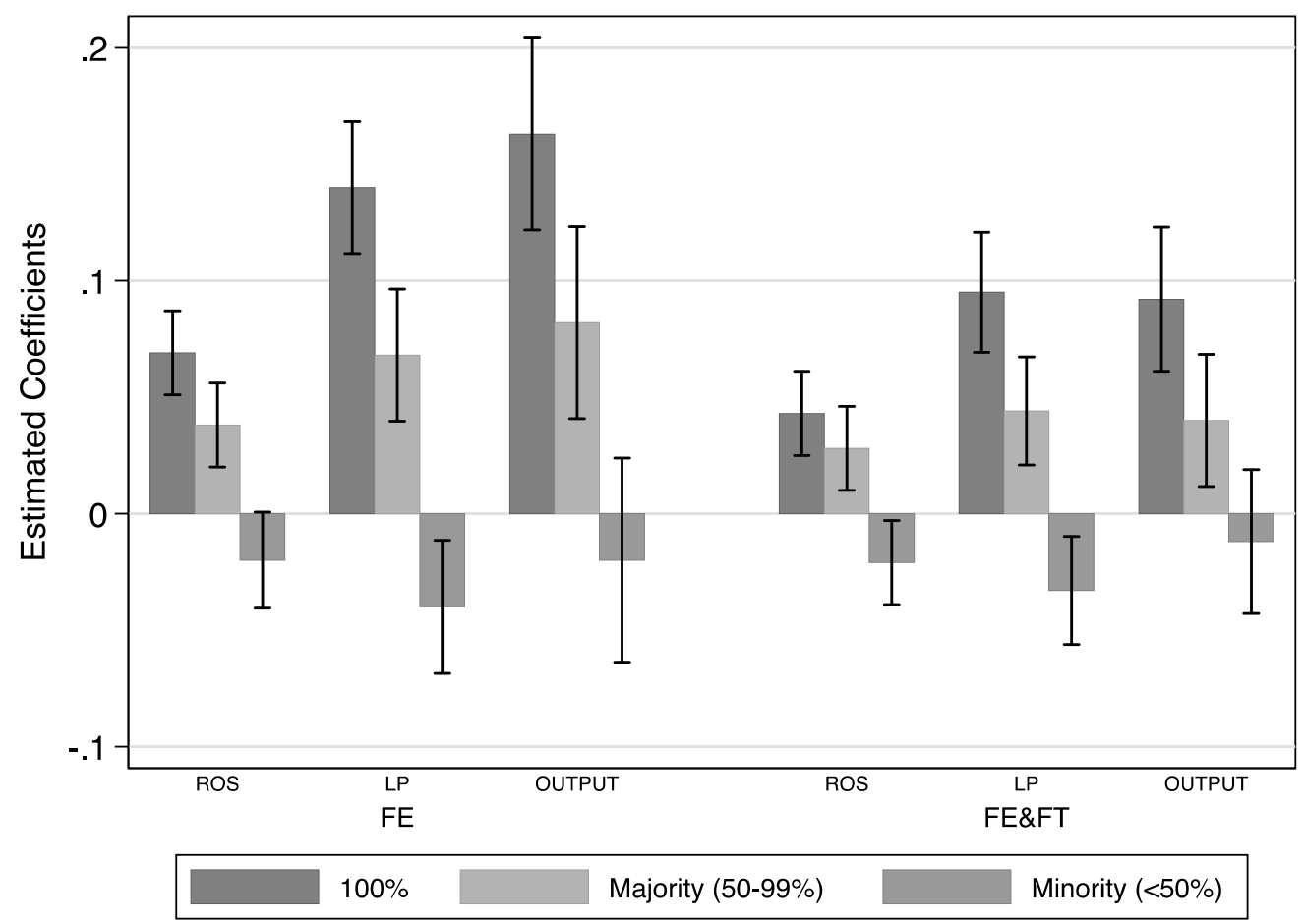

The figure presents the estimated coefficients and the 99-percent confidence interval of domestic privatizations involving a total $(100 \%)$ transfer of shares to domestic owners, a majority, but not total transfer and of minority privatizations. The definitions of the dependent variables and the privatization dummy are in Table A1. All regressions include a full set of country-industry-year interactions and a foreign dummy. FE: firm fixed effects included; FE\&FT: firm fixed effects and firm-level trends included. The coefficients and standard errors are presented in Table B6, and the country-specific estimates are shown in Table C5. 


\section{Figure 11: Estimated Effects of Domestic Privatization by Pre- Privatization Relative Employment and Labor Productivity}

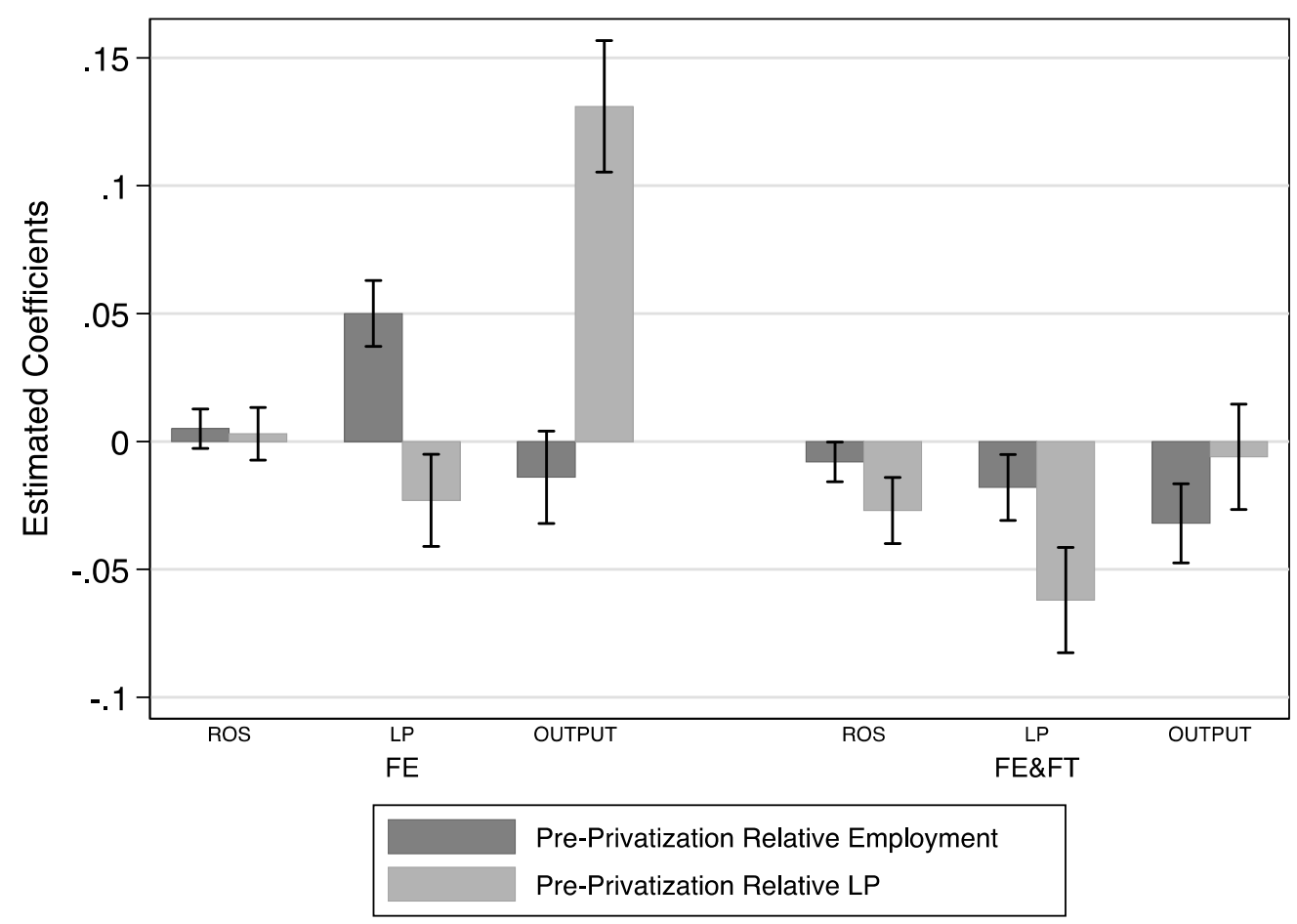

The figure presents the estimated coefficients and $99 \%$ confidence intervals for separate regressions containing interactions between a domestic privatization dummy and relative preprivatization employment size and labor productivity. Pre-privatization values of size and productivity are defined as log deviations from the country-industry-year means in the year before privatization. The precise definitions of the privatization dummy are in Table A1 and of relative employment and labor productivity in Table A2. All regressions control for a full set of country-industry-year interactions and a foreign dummy; those labelled "FE" also include firm fixed effects and those labelled "FE\&FT" include both firm fixed effects and firm-specific trends. The coefficients and standard errors from the regressions are shown in Table B7, and the country-specific estimates are shown in Tables C6 and C7. 


\section{Figure 12: Estimated Effects of Domestic Privatization by Financial Dependence and Use of Technology}

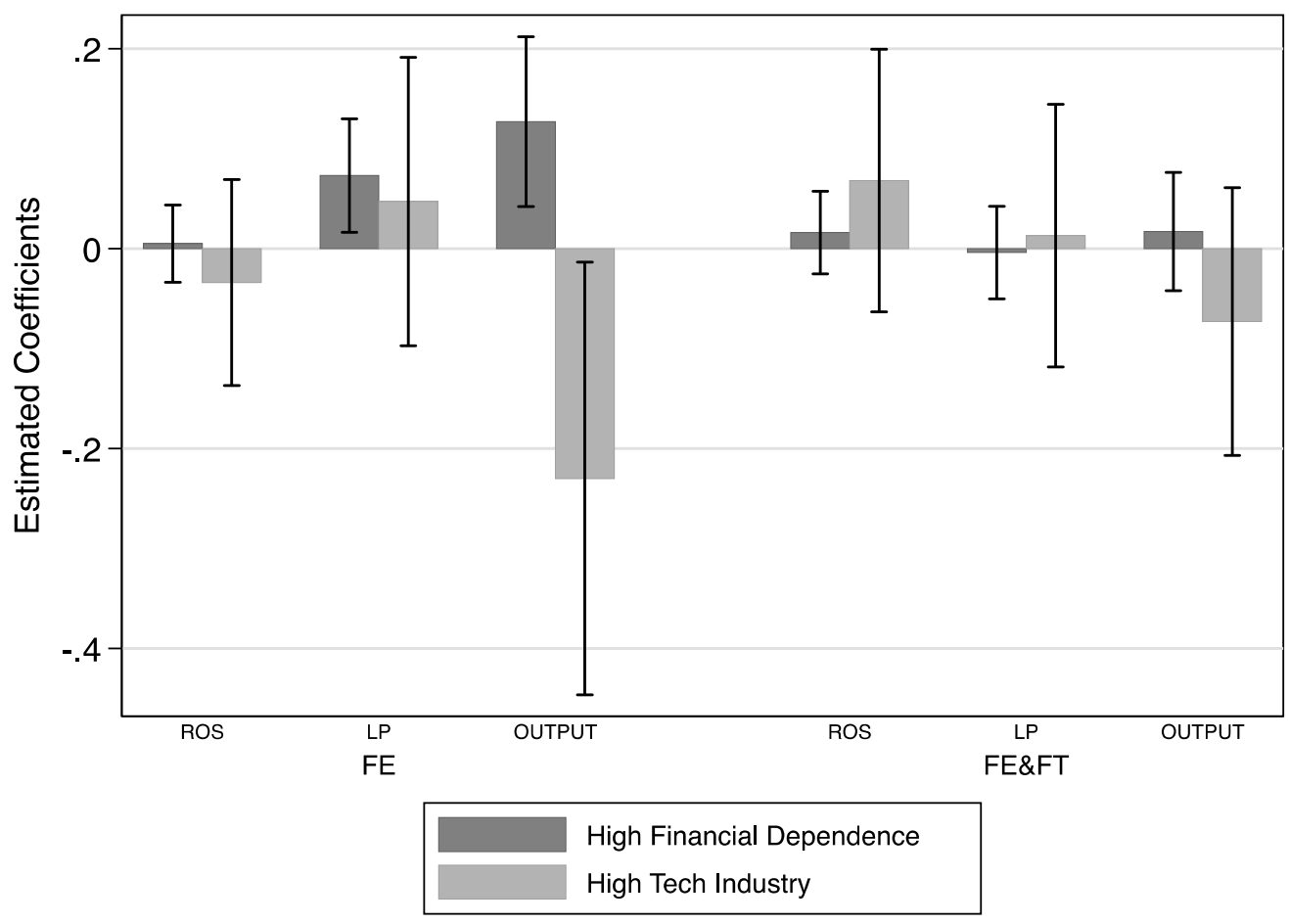

The figure presents the estimated coefficients and the 99-percent confidence interval of interactions between a domestic privatization dummy and high financial dependence and use of high technology. The definitions of the privatization dummy are in Table A1 and of financial dependence and use of high technology are in Table A2. All regressions include a full set of country-industry-year controls and a foreign dummy. FE: firm fixed effects included; FE\&FT: firm fixed effects and firm-level trends included. The coefficients (standard errors) are presented in Table B8 and the country-specific estimates are shown in Tables C8 and C9. 


\section{Figure 13: Estimated Effects of Domestic Privatization by GDP, CPI and Industrial Output Growth}

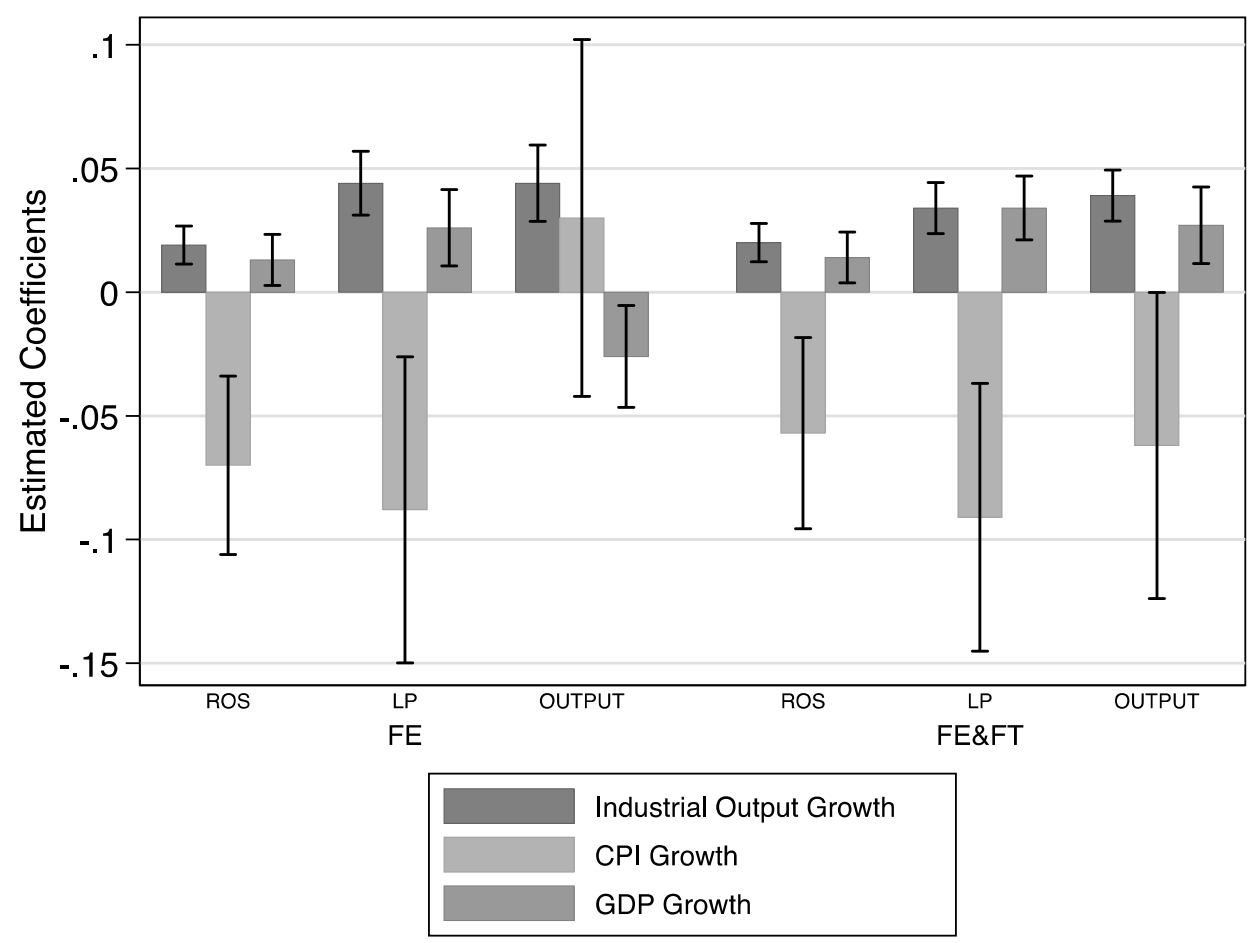

The figure presents the estimated coefficients and the 99-percent confidence intervals of interactions between a domestic privatization dummy and GDP, CPI, and 3-digit industrial output growth, respectively. The definitions of the privatization dummy are in Table A1 and of CPI, GDP, and the industrial output growth definition in Table A2. GDP, CPI, and 3-digit industrial output growth are all standardized so that the height of a bar reflects the estimated impact of a one standard deviation change. All regressions include a full set of country-industry-year interactions and a foreign dummy. FE: firm fixed effects included; FE\&FT: firm fixed effects and firm-level trends included. The coefficients and standard errors are presented in Table B9, and the country-specific estimations for aggregate industrial output are shown in Table C10. 
Figure 14: Estimated Effects of Domestic Privatization by Institutional and Policy Environment

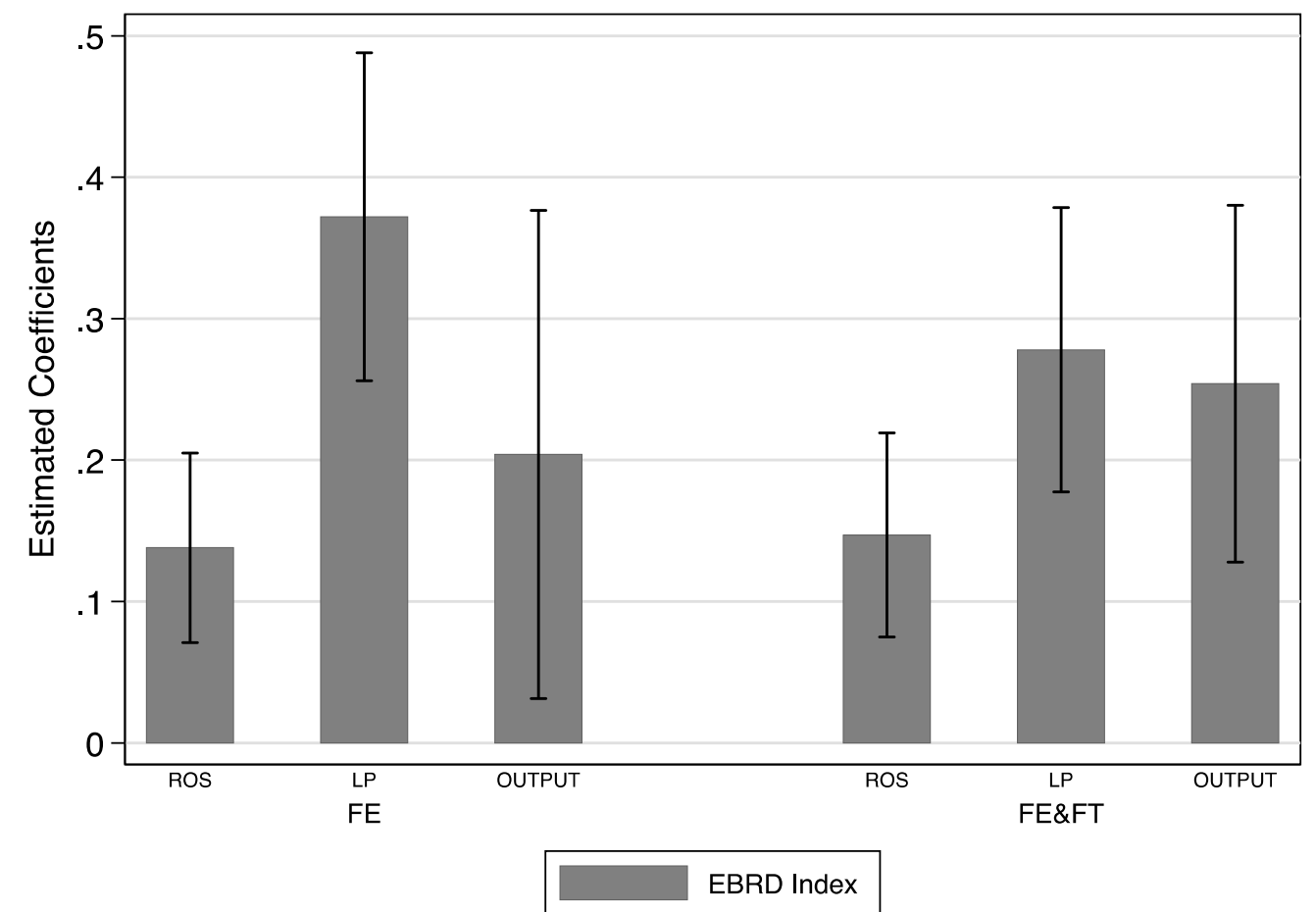

The figure presents the estimated coefficients and the 99-percent confidence intervals of interactions between a domestic privatization dummy and a composite EBRD index of progress in transition towards a market economy; the index is normalized to have $\mathrm{SD}=1$. All regressions include a full set of country-industry-year interactions and a foreign dummy. FE: firm fixed effects included; FE\&FT: firm fixed effects and firm-level trends included. The regressions are weighted such that each country has an equal weight in each year. The coefficients and standard errors are presented in Table B10. 